\title{
ACTIVE OOID GROWTH DRIVEN BY SEDIMENT TRANSPORT IN A HIGH-ENERGY SHOAL, LITTLE AMBERGRIS CAY, TURKS AND CAICOS ISLANDS
}

\author{
ELIZABETH J. TROWER, ${ }^{1,2}$ MARJORIE D. CANTINE, ${ }^{3}$ MAYA L. GOMES, ${ }^{4,5}$ JOHN P. GROTZINGER, ${ }^{2}$ ANDREW H. KNOLL, ${ }^{6}$ MICHAEL P. \\ LAMB, ${ }^{2}$ USHA LINGAPPA, ${ }^{2}$ SHANE S. O'REILLY, ${ }^{3,7}$ THEODORE M. PRESENT, ${ }^{2}$ NATHAN STEIN,${ }^{2}$ JUSTIN V. STRAUSS, ${ }^{8}$ AND WOODWARD \\ W. FISCHER ${ }^{2}$ \\ ${ }^{1}$ Department of Geological Sciences, University of Colorado Boulder, Boulder, Colorado 80309, U.S.A. \\ ${ }^{2}$ Department of Geological and Planetary Sciences, California Institute of Technology, Pasadena, California 91125, U.S.A. \\ ${ }^{3}$ Department of Earth, Atmospheric and Planetary Sciences, Massachusetts Institute of Technology, Cambridge, Massachusetts 02139, U.S.A. \\ ${ }^{4}$ Department of Earth and Planetary Sciences, Washington University in St. Louis, St. Louis, Missouri 63130, U.S.A. \\ ${ }^{5}$ Department of Earth and Planetary Sciences, Johns Hopkins University, Baltimore, Maryland 21218, U.S.A. \\ ${ }^{6}$ Department of Organismic and Evolutionary Biology, Harvard University, Cambridge, Massachusetts 02138, U.S.A. \\ ${ }^{7}$ School of Earth Sciences, University College Dublin, Dublin, Ireland \\ ${ }^{8}$ Department of Earth Sciences, Dartmouth College, Hanover, New Hampshire 03755, U.S.A. \\ e-mail: elizabeth.j.trower@colorado.edu
}

\begin{abstract}
Ooids are a common component of carbonate successions of all ages and present significant potential as paleoenvironmental proxies, if the mechanisms that control their formation and growth can be understood quantitatively. There are a number of hypotheses about the controls on ooid growth, each offering different ideas on where and how ooids accrete and what role, if any, sediment transport and abrasion might play. These hypotheses have not been well tested in the field, largely due to the inherent challenges of tracking individual grains over long timescales. This study presents a detailed field test of ooid-growth hypotheses on Little Ambergris Cay in the Turks and Caicos Islands, British Overseas Territories. This field site is characterized by westward net sediment transport from waves driven by persistent easterly trade winds. This configuration makes it possible to track changes in ooid properties along their transport path as a proxy for changes in time. Ooid size, shape, and radiocarbon age were compared along this path to determine in which environments ooids are growing or abrading. Ooid surface textures, petrographic fabrics, stable-isotope compositions $\left(\delta^{13} \mathrm{C}, \delta^{18} \mathrm{O}\right.$, and $\left.\delta^{34} \mathrm{~S}\right)$, lipid geochemistry, and genetic data were compared to characterize mechanisms of precipitation and degradation and to determine the relative contributions of abiotic (e.g., abiotic precipitation, physical abrasion) and biologically influenced processes (e.g., biologically mediated precipitation, fabric destruction through microbial microboring and micritization) to grain size and character. A convergence of evidence shows that active ooid growth occurs along the transport path in a high-energy shoal environment characterized by frequent suspended-load transport: median ooid size increases by more than $100 \mu \mathrm{m}$ and bulk radiocarbon ages decrease by $360 \mathrm{yr}$ westward along the $\sim 20 \mathrm{~km}$ length of the shoal crest. Lipid and $16 \mathrm{~S}$ rRNA data highlight a spatial disconnect between the environments with the most extensive biofilm colonization and environments with active ooid growth. Stable-isotope compositions are indistinguishable among samples, and are consistent with abiotic precipitation of aragonite from seawater. Westward increases in ooid sphericity and the abundance of well-polished ooids illustrate that ooids experience subequal amounts of growth and abrasion-in favor of net growth — as they are transported along the shoal crest. Overall, these results demonstrate that, in the Ambergris system, the mechanism of ooid growth is dominantly abiotic and the loci of ooid growth is determined by both carbonate saturation and sediment transport mode. Microbes play a largely destructive, rather than constructive, role in ooid size and fabric.
\end{abstract}

INTRODUCTION

Ooids, concentrically coated sand-size grains composed of $\mathrm{CaCO}_{3}$ minerals, are a mode of carbonate precipitation found ubiquitously in carbonate successions throughout Earth history (Wilkinson et al. 1985). Ooid grainstones are economically significant as key hydrocarbon reservoir lithofacies, and the chemical compositions of ooids have the potential to provide information about climate change and ancient seawater composition (Mackenzie and Pigott 1981; Sandberg 1983; Wilkinson et al. 1984; Wilkinson et al. 1985). In modern environments, ooids commonly, but not universally, occur in shallow, current-agitated marine settings (Newell et al. 1960; Ball 1967; Rankey and Reeder 2011), but a lack of quantitative constraints on the mechanisms and pace of ooid genesis has limited their utility for reconstructing ancient physical and chemical 
conditions. A number of hypotheses have been developed to explain the chemical, physical, and biological controls on ooid growth, but they remain untested in field settings.

Bathurst (1975) posed the first mechanistic hypothesis for ooid formation, arguing that precipitation is controlled by seawater carbonate saturation state and enabled by sediment transport conditions that allow grain suspension and radial growth. The textbook description of ooid formation invokes an "ooid factory" (the environment in which ooids form) characterized by vigorous current agitation to suspend grains and seawater sufficiently supersaturated with respect to $\mathrm{CaCO}_{3}$ to drive precipitation (Flügel 2013); such an environment is analogous to modern Bahamian ooid shoals. Davies et al. (1978), Sumner and Grotzinger (1993), and Duguid et al. (2010) argued that ooids spend much of their lifetime at rest or buried beneath the surface, with the consequence that growth occurs only during brief periods when grains are resuspended by currents. Subsequent studies have further examined the effects of sediment transport on ooid growth and size, both in terms of the physical consequences of transport (Heller et al. 1980; Medwedeff and Wilkinson 1983; Van Ee and Wanless 2008; Trower et al. 2017) and bedform-scale relationships among hydrodynamics, bed morphology, and spatial variations in ooid size (Rankey et al. 2006; Rankey et al. 2008; Reeder and Rankey 2008; Sparks and Rankey 2013).

Another major early line of inquiry focused on the possible role(s) of microbes and/or organic coatings in ooid formation (Mitterer 1972; Suess and Fütterer 1972; Fabricius 1977; Davies et al. 1978; Ferguson et al. 1978). More recent studies have noted a benthic signature in the biogeochemistry of organic matter in ooid cortices, arguing both that time spent in contact with the seafloor has significant influence on the microbiota associated with ooid surfaces and that the biofilms produced by benthic microbes may promote carbonate precipitation and, consequently, drive ooid growth (Plée et al. 2008; Diaz et al. 2013; Edgcomb et al. 2013; Summons et al. 2013; Diaz et al. 2014; Diaz et al. 2015; O'Reilly et al. 2017; Siahi et al. 2017). Some have argued that microbially mediated ooid growth occurs while grains are located in quieter-water environments, as opposed to occurring on active shoals (Summons et al. 2013; Mariotti et al. 2014; O'Reilly et al. 2017); this concept is similar to Bathurst's (1975) early suggestion that "ooids begin to grow in the deeper water and move toward the crest of the shoal as they become larger." Other recent studies have argued that microbes might also play a role in ooid growth even in more energetic environments (Diaz et al. 2015; Diaz et al. 2017). Finally, others have suggested that the activities of microbes are primarily fabricdestructive (in the form of microborings and micritization) rather than constructive (Newell et al. 1960; Bathurst 1975; Harris et al. 1979; Duguid et al. 2010) - and thus the activities of microbial communities when ooids are at rest might reflect an overall process of mass loss, if anything. Thus the contributions of microbial communities to processes of ooid growth and degradation remain an open area of inquiry.

Some sedimentologists have long argued that ooid size reflects a balance between the competing processes of accretion and abrasion (e.g., Heller et al. 1980; Swett and Knoll 1989). In recent laboratory experiments, Trower et al. (2017) documented instantaneous rates of ooid precipitation and abrasion four or more orders of magnitude higher than slow net growth rates revealed by sequential ${ }^{14} \mathrm{C}$ dating (Beaupré et al. 2015). This rate disparity yields an explicit and testable hypothesis that ooid size is a dynamic trait that rapidly approaches an equilibrium. Small imbalances between the relatively large accretion and abrasion rates cause rapid changes in ooid size, which in turn affects sediment transport dynamics and therefore abrasion rates. Under constant environmental forcing, this feedback is expected to drive ooids towards a stable size, referred to as a dynamic equilibrium, where the rates of accretion and abrasion are in balance. A key corollary is that variable ooid sizes are predicted to reflect variable environmental conditions and different but equal accretion and abrasion rates. The experiments of Trower et al. (2017) demonstrated that the mode of sediment transport (e.g., bedload versus suspended load) provides an important, albeit previously unquantified, control on ooid size: abrasion rates for a given grain size decrease with increasing current energy because the increase in transport by suspension results in fewer grain impacts. The dynamic-equilibrium hypothesis has potential value for understanding patterns of ooid growth in modern systems because it predicts that the rate of ooid size change (either net growth or net abrasion) is uniquely set by carbonate precipitation rates and sediment transport. This hypothesis is also testable in a modern system with observations of ooid size, carbonate chemistry, and bed shear stress.

The hypotheses of ooid formation have not been well tested, in part due to the challenge of tracking the movement of individual grains in a modern oolitic system over the millennial timescales of ooid growth and transport. The maximum ages of modern ooids revealed by radiocarbon dating are on the order of 1000-2000 years, indicating very low net growth rates (Duguid et al. 2010; Beaupré et al. 2015). Instead, an independent approach to examining the relationship between ooid transport and growth is required. In principle, an oolitic system with unidirectional sediment transport would resolve the challenge of observing slow net rates by allowing distance along the transport path to substitute for time. This relationship would hold as long as there is not substantial exchange or addition of ooids from adjacent environments. In such a unidirectional sediment transport system, trends in ooid size and radiocarbon content along the transport path could be applied to test hypotheses about the environments in which ooids form (Fig. 1). Furthermore, observations of grain size and radiocarbon content provide a means of testing whether the assumption of minimal lateral mixing is appropriate (Fig. 1A). This study presents an analysis of spatial variations in ooid size, shape, surface texture, internal fabric, age, geochemistry, and microbial community in a modern oolitic shoal complex with a pattern of net unidirectional sediment transport. Together, these datasets enable assessment of spatial and temporal variations in the key processes that may affect ooid growth: physical processes - transport and abrasion, chemical processes - abiotic carbonate precipitation, and biological processes-biofilm-mediated carbonate precipitation and destruction of primary fabrics by microboring organisms.

\section{STUDY APPROACH AND METHODS}

\section{Study Location and Sample Collection}

The Caicos Platform in the Turks and Caicos Islands, British Overseas Territories, provides a classic example of a wind-dominated carbonate platform (Wanless et al. 1989; Dravis and Wanless 2008, 2017). Little Ambergris Cay is located $\sim 15 \mathrm{~km}$ north of the Caicos Platform southern margin (Fig. 2). The island forms part of an expansive modern ooid shoal complex, thereby providing a natural laboratory to examine the effects of transport on ooid size, shape, and fabric. Sustained easterly winds averaging $8.0 \pm 2.6 \mathrm{~m} / \mathrm{s}$ (Fig. 3A, B) drive currents westward along the $\sim 7 \mathrm{~km}$ shoreline of Little Ambergris Cay and then along an $\sim 20$-km-long ooid-shoal crest (Supplemental Fig. S1, see Supplemental Material). Tidal range is less than $1 \mathrm{~m}$ (NOAA/NOS/CO-OPS 2016). Wanless and Dravis (2008) concluded that tidal currents had little influence on sediment transport on the Ambergris shoal relative to wave-generated currents, but Rankey et al. (2008) suggested that tidal currents may also play a role in observed asymmetry in bedform morphology and orientation. Caicos Platform experiences tropical storms almost yearly (Wanless and Dravis 2008 ) and hurricane-force winds every $\sim 5.5$ years (Neuman et al. 1978); the most recent hurricanes to pass over Caicos Platform were hurricanes Hannah and Ike in September 2008 (Bachtel et al. 2011) and Hurricane Irma in September 2017.

Sample collection and field observations were undertaken during July 2016 and August 2017. In 2016, 51 samples of ooid sand were collected 


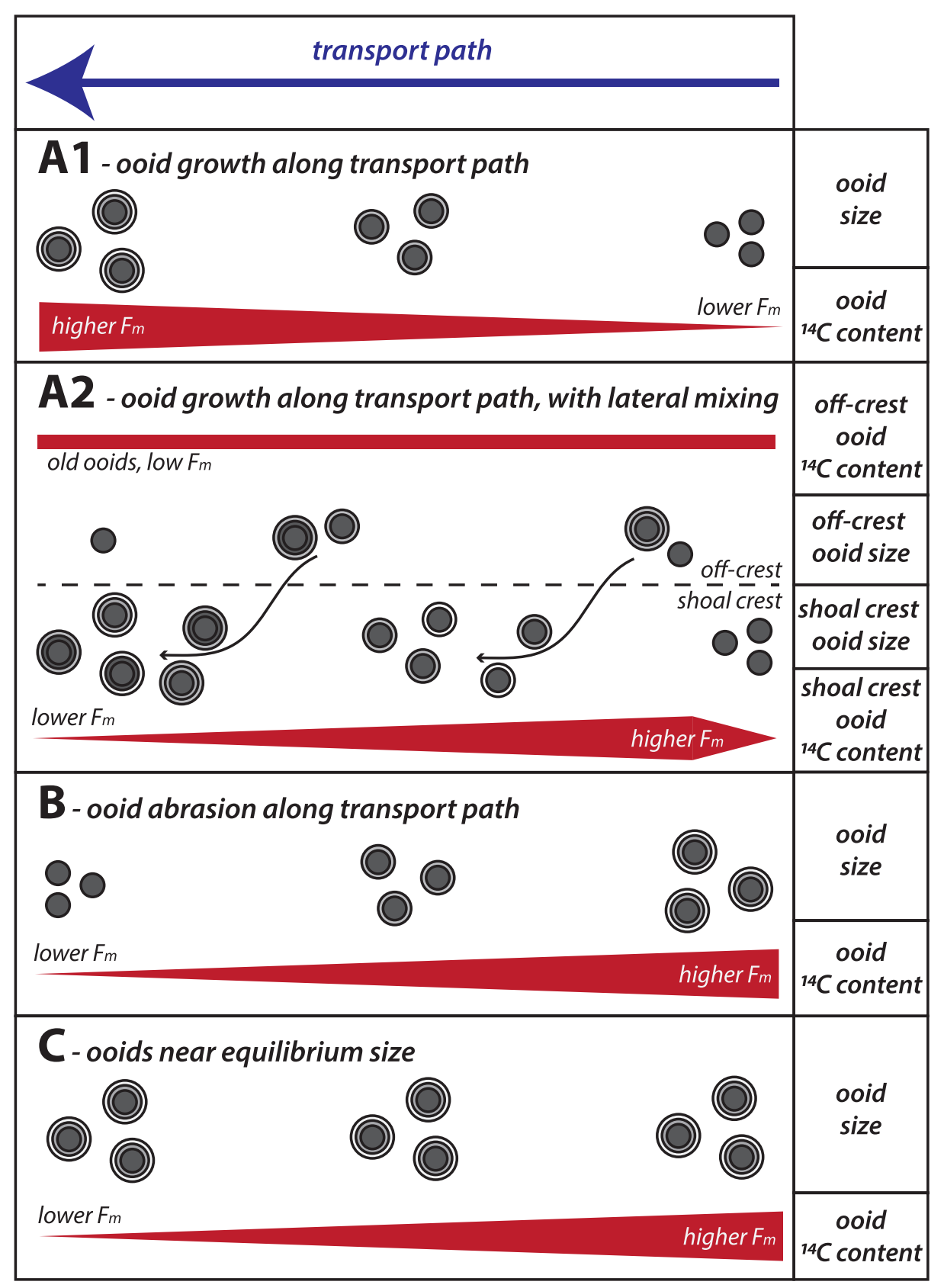

FIG. 1.-Contrasting conceptual models for ooid growth (expressed as changes in ooid size and radiocarbon age) along a unidirectional transport path. A) If ooids are net growing along the transport path, their size should increase and their radiocarbon content, expressed as Fraction Modern $F_{m}$, should increase as new young material is added and offsets older material in the nucleus and interior cortex (A1). However, if there is significant lateral mixing (i.e., a "leaky" conveyer belt) with adjacent older sediment, average radiocarbon content should decrease as ooids with young material are exchanged for older ooids (A2). If there is net growth along the transport path, the degree of lateral mixing can therefore be evaluated using radiocarbon data. B) If ooids are net abrading along the transport path, one expects the opposite trend-decreasing ooid size and radiocarbon content as outer layers with the highest radiocarbon content are removed. C) If ooid size is near equilibrium, then ooid size should stay constant along the transport path and $F_{m}$ decreases as ${ }^{14} \mathrm{C}$ decays in both the nucleus and the cortex. See Supplemental Figure S5 for further illustration of evolution of bulk ooid $F_{m}$ during growth. along the presumed direction of net transport, including a transect of 13 samples from ripple tops in the intertidal zone along the northern shore of the cay and 25 samples from ripple tops on subaqueous dune crests along the length of the shoal crest (Fig. 2). Additional samples were collected from an isolated inter-cay shoal near the airport runway on neighboring Big Ambergris Cay (3), from a bar in a tidal inlet (1) and its associated ebb (1) tidal delta, from outside the zone of active transport where incipient hardgrounds occur (7), and along the leading edge (1) of a dune in the shoal crest (Fig. 2C). In 2017, five additional ooid samples were collected every $\sim 2 \mathrm{~km}$ along the eastern half of the shoal crest to compare with the 2016 sample transect. All oolitic sediment samples were rinsed in fresh water and dried within hours of collection to prevent chloride and sulfate salts from precipitating on grain surfaces.

In 2017, seawater samples were collected from eight locations (Fig. 2): a transect of 6 locations $\sim 2 \mathrm{~km}$ apart along the length of the shoal crest (including the locations of the 2017 ooid sample set), one sample from the inter-cay shoal near the airport runway on Big Ambergris Cay, and one sample from a tidal inlet on the southern shore of Little Ambergris Cay.

\section{Observations of Sediment Transport}

An underwater camera anchored to the seafloor was used to record videos of sediment transport, including observations from the crests and troughs of dunes near the eastern end of the shoal crest, both along and orthogonal to dune strike, from the inter-cay shoal near the runway on Big Ambergris Cay, the intertidal zone on the southern shore of Little Ambergris Cay, and an ebb tidal delta on the southern shore of Little Ambergris Cay. Observations of transport conditions were repeated on multiple days and at high-tide, low-tide, and mid-tide stages during both field seasons. These videos were used, along with in situ measurements 

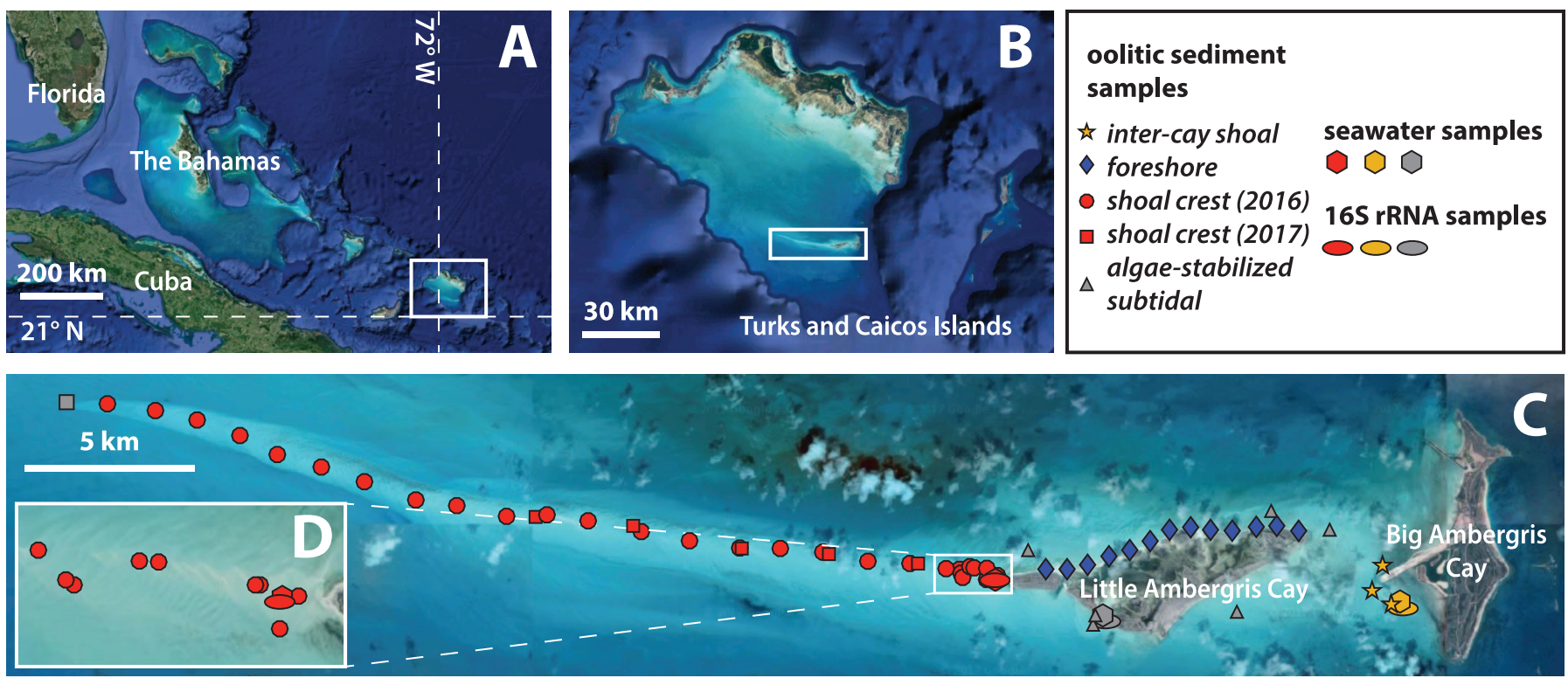

FIg. 2.-A, B) Study-area overview maps and C) sample locations, with D) inset for samples near western end of Little Ambergris Cay. Satellite images from Google and DigitalGlobe.

and observations, to characterize the dimensions of ripples and dune heights and document dominant modes of sediment transport (e.g., bed load vs. suspended load). Although small bed forms like ripples are ephemeral features - ripples can wash out and re-form in minutes - they are useful for characterizing modes of sediment transport. The degree of sediment compaction on leading and trailing edges of dunes was also compared qualitatively.

\section{Remote-Sensing Data}

Dune motion was tracked in a series of $15 \mathrm{~m} /$ pixel Landsat 8 panchromatic images. Cloud-free images were selected from February 6, 2016, April 20, 2016, June 24, 2016, October 19, 2016, and January 5, 2017; this temporal sampling was chosen so that movement of each dune was resolvable between frames ( $\geq 2$ pixels). Dunes that matched between images were identified visually (Supplemental Fig. S2). The displacement of each point was calculated along the strike of the shoal crest and averaged over all points. To measure wavelengths and orientations, dunes were mapped visually in a $50 \mathrm{~cm} /$ pixel Worldview-2 satellite image of the shoal collected on March 25, 2013. Crestlines were traced visually along 196 dune crests using ENVI software. Dip directions of the slip faces of the asymmetrical dunes were computed as the direction orthogonal to each crest line. Wavelengths of the dunes were computed by tracing lines in the average dip direction of wave sets and tabulating the distance between individual wave crests. UAV imagery and photomosaics were used to observe tidal bar migration and elongation between 2016 and 2017.

\section{Grain-Size Analysis}

Ooid size and shape characteristics were determined using a Retsch Camsizer P4 at the California Institute of Technology Sedimentology Laboratory. In addition to intermediate-axis grain diameter (equivalent to sieve diameter), three shape statistics for comparing samples include: (1) aspect ratio (ratio of the long-axis to the short-axis dimensions of a grain in cross section), (2) sphericity (a measure of the divergence of a shape from a perfect sphere, calculated as $4 \pi A / p^{2}$, where $p$ is the perimeter and $A$ is the area of the particle projection; a perfect sphere has a sphericity of unity and other shapes have sphericity of less than unity), and (3) roundness (applying the Wadell roundness index, calculated as $\Sigma r_{i} /(n R)$, where $r_{i}$ are the radii of curvature of particle corners, $R$ is the radius of the largest inscribed circle, and $n$ is the number of particle corners measured; Wadell 1932). A sorting statistic can also be defined as the difference between the 90th percentile $\left(D_{90}\right)$ and 10th percentile $\left(D_{10}\right)$ grain diameters normalized by the median grain diameter $\left(D_{50}\right):\left(D_{90}-D_{10}\right) / D_{50}$. The raw data set, including size and shape characteristics for every grain analyzed, was processed using a conservative shape threshold (sphericity and roundness $>0.8$ ) to filter out grapestones and skeletal fragments and to compare ooid populations directly without the confounding effects of different proportions of non-ooid grains.

\section{Microscopy}

Loose ooids from eleven representative samples were embedded in epoxy and prepared as polished thin sections for transmitted-light and reflected-light microscopy. Volume ratios of ooid cortices to nuclei were estimated by tracing out contacts in JMicroVision (Roduit 2007) with a stylus, and corrected for spherical segment of particle cross sections viewed in thin section using grain-size distributions from Camsizer data. Proportions of distinct grain fabrics (micritized, non-micritized, and mixed fabric; see Results for further discussion) were point counted using JMicroVision and mosaic images of full thin sections (600 points per sample). Sediment compositions (single ooids, grapestones, skeletal fragments, and peloids) were determined by point counting with JMicrovision (600 points per sample).

Loose whole ooids were mounted on aluminum stubs with carbon tape and carbon coated for scanning-electron-microscope (SEM) imaging using a Zeiss 1550VP Field Emission SEM at the Caltech GPS Division Analytical Facility (accelerating voltage $15-20 \mathrm{kV}$, working distance 16-20 $\mathrm{mm})$. Selected polished thin sections were etched with $1 \% \mathrm{HCl}$ for 1 minute, dissolving the upper layer of carbonate but leaving casts of microboring traces in outermost cortices that were filled with epoxy by the embedding process during thin-section preparation. These etched thin sections were coated with Pd for SEM imaging (accelerating voltage 15-20 $\mathrm{kV}$, working distance $16-20 \mathrm{~mm}$ ) to characterize the morphology of microboring traces. 


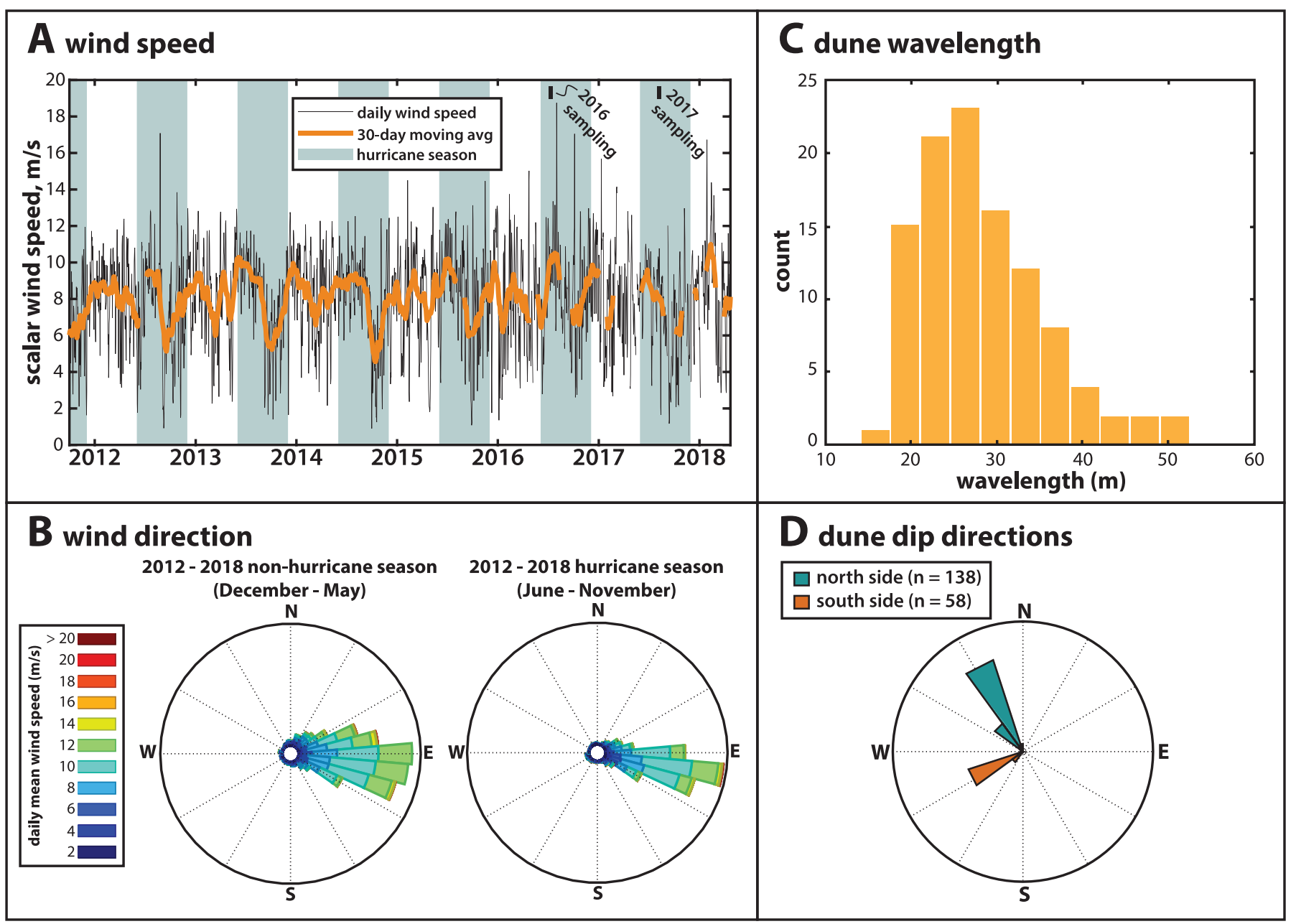

FIg. 3.-Wind-speed data (A, B) and C, D) data on dune dimensions and orientation. A) Wind speeds and 30-day moving average for the years 2012-2017, indicating consistently average wind speeds of $\sim 8 \mathrm{~m} / \mathrm{s}$ (see Supplement for code to download and plot this data set from the National Centers for Environmental Information archive). B) Wind rose diagram with data binned by wind speed for the same time period as shown in part A, indicating consistent wind direction, oriented nearly due west. These wind directions drive predominantly westward sea-surface currents (Supplemental Fig. S1). C) Histogram of dune wavelengths estimated from Worldview-2 satellite imagery. D) Dune dip directions calculated from satellite images, showing consistent and distinct orientations on the north and south sides of the shoal crest.

Aliquots of representative samples spanning the length of the shoal crest were photographed at high resolution and magnification under a stereomicroscope. Randomly chosen grains were characterized as highly polished, slightly pitted, moderately pitted, or highly pitted; 250 individual ooids from each sample were characterized using the point-counting function in JMicroVision. SEM images were used to examine the microtexture of "pitting" on ooid surfaces in greater detail.

\section{Geochemistry}

Radiocarbon Dating.-Eight samples from 2016 and five samples from 2017 (10-15 mg of loose whole ooids each) were analyzed for bulk radiocarbon content of the carbonate. The radiocarbon sample set from 2016 included five samples spanning the length of the shoal crest, two samples from the intertidal zone along the northern edge of the island, and a final sample from the isolated inter-cay shoal near the runway on Big Ambergris Cay. The radiocarbon sample set from 2017 included five samples spanning the eastern $\sim 10 \mathrm{~km}$ of the shoal crest to compare with the 2016 dataset. Samples were sent to the NOSAMS facility at the Woods Hole Oceanographic Institution (Pearson et al. 1997) and data are reported as Fraction Modern $\left(F_{m}\right)$-a measure of the deviation of ${ }^{14} \mathrm{C} /{ }^{12} \mathrm{C}$ of the sample from a "Modern" value, where Modern is defined as 95\% of 1.176 $\pm 0.010 \times 10^{-12}$ (Karlen et al. 1965). The local radiocarbon reservoir age is $238 \pm 10 \mathrm{yr}$ (Wagner et al. 2009).

Isotope Analyses.-Samples for bulk carbonate carbon $\left(\delta^{13} \mathrm{C}_{\text {carb }}\right)$ and oxygen $\left(\delta^{18} \mathrm{O}_{\text {carb }}\right)$ isotopes, and carbonate-associated sulfate extractions (CAS) for sulfur $\left(\delta^{34} \mathrm{~S}_{\mathrm{CAS}}\right)$ isotopic analyses were crushed to a fine powder using a SPEX shatterbox with a tungsten carbide vessel. Three samples were processed that span the length of the shoal crest, two samples from algae-stabilized subtidal settings off the shores of the cay, and one sample from the small shoal near the runway. Bulk $\delta^{13} \mathrm{C}_{\text {carb }}$ and $\delta^{18} \mathrm{O}_{\text {carb }}$ compositions of powdered ooid samples were measured in the Isotope Biogeochemistry Laboratory at Washington University on a ThermoElectron Delta V Advantage isotope-ratio mass spectrometer by reaction with $100 \% \mathrm{H}_{3} \mathrm{PO}_{4}$ at $25^{\circ} \mathrm{C}$ in a $\mathrm{N}_{2}$-purged vessel in a GasBench II heating block. Isotope compositions are reported as permil deviations from the Vienna Pee Dee Belemnite (V-PDB) using standard delta notation $\left(\delta^{13} \mathrm{C}=\right.$ $\left[\left(\left({ }^{13} \mathrm{C} /{ }^{12} \mathrm{C}\right)_{\text {sample }} /\left({ }^{13} \mathrm{C} /{ }^{12} \mathrm{C}\right)_{\mathrm{V}-\mathrm{PDB}}\right)-1\right] \times 1000 ; \delta^{18} \mathrm{O}=\left[\left(\left({ }^{18} \mathrm{O} /{ }^{16} \mathrm{O}\right)_{\text {sample }} /\right.\right.$ $\left.\left.\left.\left({ }^{18} \mathrm{O} /{ }^{16} \mathrm{O}\right)_{\mathrm{V}-\mathrm{PDB}}\right)-1\right] \times 1000\right)$. Carbonate $\delta^{13} \mathrm{C}$ and $\delta^{18} \mathrm{O}$ data are reproducible within $0.1 \%$ and $0.3 \%$, respectively, based on repeated analyses of laboratory standards. 
CAS was extracted from carbonate samples using standard techniques (after Burdett et al. 1989) with additional rinse steps to ensure complete removal of non-CAS sulfur phases (after Wotte et al. 2012). Details of CAS extractions and collection methods for seawater sulfate are provided in the supplemental material. Sulfur isotopes $\left(\delta^{34} \mathrm{~S}_{\mathrm{CAS}}\right)$ were measured on carbonate-associated sulfate and seawater sulfate in the Biogeochemistry Laboratory at Washington University on a ThermoElectron Delta V continuous-flow isotope-ratio mass spectrometer via combustion of $\mathrm{BaSO}_{4}$ with $\mathrm{V}_{2} \mathrm{O}_{5}$ to $\mathrm{SO}_{2}$ gas. Isotopic compositions are reported as permil deviations from the Vienna Canyon Diablo Troilite (V-CDT) using standard delta notation $\left(\delta^{34} \mathrm{~S}=\left[\left(\left({ }^{34} \mathrm{~S} /{ }^{32} \mathrm{~S}\right)_{\text {sample }} /\left({ }^{34} \mathrm{~S} /{ }^{32} \mathrm{~S}\right)_{\mathrm{V}-\mathrm{CDT}}\right)-1\right] \times\right.$ 1000). Sulfur-isotope data are reproducible within $0.2 \%$ based on repeated analyses of samples and international standards (IAEA-SO5, and NBS127).

Seawater Chemistry.-Salinity was measured in the field using a handheld refractometer, which is accurate to $\sim 1 \%$. $\mathrm{pH}$ was also measured in the field using a WTW $3310 \mathrm{pH}$ meter with a SenTix $41 \mathrm{pH}$ probe, which was calibrated daily in the field using fresh $\mathrm{pH} \mathrm{4,} \mathrm{7,} \mathrm{and} 10$ buffer solutions. Samples for the concentration and carbon-isotope composition of dissolved inorganic carbon (DIC) were collected in triplicate in the field and analyzed at the California Institute of Technology by continuous-flow isotope-ratio mass spectrometry (Torres et al. 2005). Precision was determined from the triplicates of sample aliquots, and was 0.04-0.16 $\mathrm{mmol} / \mathrm{kg}(1 \sigma$ standard error [s.e.]). One sample from one triplicate sample set was identified as an outlier and has been omitted from the reported data. Carbon-isotope ratios of the samples' headspace $\mathrm{CO}_{2}$ are reported as $\delta^{13} \mathrm{C}_{\text {DIC }}$. Precision was $0.05-0.16 \%$ o ( $1 \sigma$ s.e. $)$, as determined from the triplicate analyses of each sample.

Seawater aliquots for determining the concentration of total alkalinity were collected in the field and analyzed by open-system Gran titration (e.g., Subhas et al. 2015). Uncertainty in the alkalinity deriving from fitting the Gran function was $0.018-0.020 \mathrm{meq} / \mathrm{kg}$. Using the Matlab code CO2SYS (Lewis et al. 1998; Van Heuven et al. 2011), DIC, alkalinity, pH, and salinity data were used to calculate $\Omega_{\text {aragonite, }}$, the saturation state of aragonite. Calculations were performed using a temperature of $30^{\circ} \mathrm{C}$. More detailed descriptions of methodology are provided in Supplemental Material.

16S rRNA Analysis.- Three locations were selected for triplicate $16 \mathrm{~S}$ rRNA analysis in August 2017, one each from shoal crest, inter-cay shoal, and algae-stabilized subtidal environments. DNA was extracted using the Zymo Soil/Fecal DNA MiniPrep kit. A segment of the 16S rRNA gene was amplified by polymerase chain reaction (PCR) using primers that amplify both Bacteria and Archaea (Parada et al. 2016). PCR product was barcoded and sequenced using the iTag approach (Caporaso et al. 2012; Degnan and Ochman 2012) on a MiSeq Illumina sequencing platform. The data were processed using QIIME (Caporaso et al. 2010) to generate abundance tables of the microbial communities identified in each sample (Case et al. 2015). Sequences were deposited in the publically available NCBI Sequence Read Archive. Taxonomy charts were generated using Krona (Ondov et al. 2011).

Lipid Analysis.-Eight samples were selected for lipid analysis: one from the inter-cay shoal, three samples spanning the length of the shoal crest, and four samples from algae-stabilized subtidal environments adjacent to the shoal crest or Little Ambergris Cay. Lipids from whole ooids were extracted according to a modified Bligh and Dyer method (Bligh and Dyer 1959; Sturt et al. 2004; O’Reilly et al. 2017); the extracted lipids are representative of the grain surfaces. Intact Polar Lipids (IPLs) were analyzed via high-performance liquid chromatography mass spectrometry using an Agilent 1200 Series HPLC coupled to an Agilent
Accurate-Mass Quadrupole Time-of-Flight mass spectrometer and an electrospray ionization (ESI) interface. A description of the methodology is provided in Supplemental material. Identification of lipids were based on exact masses of parent ions as $\mathrm{H}^{+}$or $\mathrm{NH}_{4}{ }^{+}$adduct ions in combination with diagnostic fragment ions and/or neutral losses in accompanying $\mathrm{MS}^{2}$ scans. All data processing was performed using MZmine 2 (Pluskal et al. 2010). Lipids were assigned to taxonomic groups based on the combined composition of polar head groups, core carbon chain length and degree of chain unsaturation and with reference to published literature (cf. Table 2 in O'Reilly et al. 2017).

\section{RESULTS}

\section{Hydrodynamics, Sediment Transport, and Bedforms}

The mean wind velocity during the sampling and observation period was $10 \mathrm{~m} / \mathrm{s}$ from $104^{\circ}$ (i.e., nearly due east), within the ranges of typical wind speed and direction over the last 6 years (Fig. 3A; median wind speed $8.3 \mathrm{~m} / \mathrm{s}$, median wind direction $96^{\circ}$ ) (see Supplemental Material for Matlab code used to download and plot wind data from NOAA National Centers for Environmental Information daily blended wind dataset). Based on wind, tide, and current data, the transport conditions observed likely represent typical fair-weather conditions, and our observations match those made over the last several decades (Wanless et al. 1989; Wanless and Dravis 2008) with respect to the intermittent exposure of dune crests at low tide near the island, average water depths observed along the shoal, and vigorous current energy observed along dune crests at mid tide. This similarity in sediment transport conditions is expected due to the position of these environments in the steady easterly trade winds (Fig. 3). There were some differences in the large-scale geomorphology of the shoal crest between our observation periods in 2016 and 2017 and that documented by Rankey et al. (2008), particularly the absence of regular variations in shoal crest width described in 2008. This difference may reflect long-term readjustment of the morphology (amplitude and orientation) of shoal bedforms after near-passes by hurricanes Hannah and Ike in September 2008 (Bachtel et al. 2011). Nevertheless, the sizes and orientations of dunes were comparable in our field seasons to those observed before the 2008 hurricanes (Rankey et al. 2008; Bachtel et al. 2011).

At the time of field observations (July 2016 and August 2017), five environments with oolitic sands from Little Ambergris Cay could be categorized based on water depth, sediment transport mode, and bedforms (Fig. 2C, Table 1): (1) inter-cay shoal, (2) foreshore, (3) shoal crest, (4) algae-stabilized subtidal environments, and (5) supratidal and cay-interior environments. The following analyses focused on the first four environments; there is undoubtedly some exchange of ooids between supratidal and cay-interior environments and the more active parts of the system, but fair-weather grain transport fluxes in those systems are low.

Wave patterns in the Ambergris shoal complex record wave refraction around Big Ambergris Cay: wave fronts oriented orthogonal to the prevailing wind direction (Fig. 3B) are roughly parallel to the eastern shoreline of Big Ambergris Cay as they approach from the east, but are then refracted around Big and Little Ambergris Cays, creating two sets of wave orientations and longshore currents on the north and south sides of the system (cf. Fig. 3.5-7 in Kinsman 1965). Along the shores of Little Ambergris Cay, this refraction pattern should produce wave trains that are directed nearly orthogonal to the northern and southern shorelines, whereas on the shoal crest, the two sets of wave trains should be roughly orthogonal to each other - the northern waves directed SW and the southern waves directed NW. Wave patterns matched these predictions during our observation period. For example, conditions on the shoal crest are chaotic and energetic at mid-tide as nearly orthogonal wave fronts interfere and reflect, breaking along the shoal crest; previous workers have described this effect as resulting in a "washing machine"-like experience for snorkelers 
TABLE 1.-Descriptions of ooid environments.

\begin{tabular}{|c|c|c|c|c|c|}
\hline $\begin{array}{l}\text { Environment } \\
\text { Type }\end{array}$ & Water Depth & $\begin{array}{c}\text { Sediment Transport } \\
\text { Mode }\end{array}$ & Spatial Association & Bedforms & $\begin{array}{l}\text { Typical Sediment } \\
\text { Characteristics }\end{array}$ \\
\hline Inter-cay shoal & $\begin{array}{l}\text { Shallow subtidal }(\sim 1 \\
\quad \mathrm{m})\end{array}$ & Dominantly bed load & $\begin{array}{l}\text { Adjacent to end of runway on } \\
\text { Big Ambergris Cay }\end{array}$ & $\begin{array}{l}10-25 \mathrm{~cm} \text { amplitude sand } \\
\text { waves, cm-scale wave } \\
\text { ripples }\end{array}$ & $\begin{array}{l}\text { Well-sorted fine-sand-size } \\
\text { ooids }\end{array}$ \\
\hline Foreshore & $\begin{array}{l}\text { Intertidal to shallow } \\
\text { subtidal }(0-0.5 \mathrm{~m})\end{array}$ & $\begin{array}{l}\text { Threshold for motion to } \\
\text { bed load }\end{array}$ & $\begin{array}{l}\text { Foreshore and upper shoreface } \\
\text { along Little Ambergris Cay }\end{array}$ & Symmetrical wave ripples & $\begin{array}{l}\text { Moderately well-sorted } \\
\text { medium-sand-size ooids } \\
\text { with coarser skeletal } \\
\text { fragment lags }\end{array}$ \\
\hline Shoal crest & $\begin{array}{l}\text { Intertidal to shallow } \\
\text { subtidal }\end{array}$ & Threshold of suspension & $\begin{array}{l}\text { 20-km-long shoal extending } \\
\text { west of Little Ambergris } \\
\text { Cay }\end{array}$ & $\begin{array}{l}30-50 \mathrm{~cm} \text { amplitude sand } \\
\text { waves, cm-scale wave } \\
\text { ripples }\end{array}$ & $\begin{array}{l}\text { Well-sorted medium-sand-size } \\
\text { ooids }\end{array}$ \\
\hline $\begin{array}{l}\text { Algae-stabilized } \\
\text { subtidal }\end{array}$ & Deeper subtidal & $\begin{array}{l}\text { Below threshold for } \\
\text { motion }\end{array}$ & $\begin{array}{l}\text { Deeper-water zones adjacent to } \\
\text { runway shoal, beach, and } \\
\text { main shoal environments }\end{array}$ & $\begin{array}{l}\text { Inactive sand waves in } \\
\text { some areas }\end{array}$ & $\begin{array}{l}\text { Moderately sorted medium } \\
\text { sand-size ooid and skeletal } \\
\text { carbonate sand including } \\
\text { algal fragments and } \\
\text { grapestones }\end{array}$ \\
\hline $\begin{array}{l}\text { Supratidal and cay } \\
\text { interior }\end{array}$ & $\begin{array}{l}\text { Supratidal and } \\
\text { intertidal (cay } \\
\text { interior) }\end{array}$ & $\begin{array}{l}\text { Aeolian (supratidal), below } \\
\text { threshold for motion } \\
\text { (cay interior) }\end{array}$ & $\begin{array}{l}\text { Supratidal beaches, Holocene } \\
\text { bedrock ridges, storm } \\
\text { deposits of ooid sands } \\
\text { within the interior lagoon }\end{array}$ & Wind ripples & $\begin{array}{l}\text { Varied sorting and grain sizes } \\
\text { of ooid sand }\end{array}$ \\
\hline
\end{tabular}

(Wanless and Dravis 2008; Dravis and Wanless 2017) and this wave refraction pattern appears to be a long-lived characteristic of the Ambergris system (Wanless and Dravis 1989; Wanless and Dravis 2008; Dravis and Wanless 2017). The morphologic asymmetry of the shoal crest described by Rankey et al. (2008) may reflect subtle asymmetry in the wave refraction pattern caused by bathymetric asymmetry-the orientations, wavelengths, and amplitudes of refracting waves are sensitive to subtle differences in water depth (Kinsman 1965) and the bathymetry of the platform is different on the north and south sides of Little Ambergris Cay (Harris and Ellis 2008) - in addition to the effects of tidal currents and storms.

In the inter-cay shoal environment, ooids occur in a spatially restricted shoal covering less than $0.4 \mathrm{~km}^{2}$ adjacent to the end of the runway on Big Ambergris Cay. The southern part of this small shoal is characterized by a series of linear, NW-SE-striking, asymmetric subaqueous dunes with wavelengths of $\sim 30-60 \mathrm{~m}$ and amplitudes of $\sim 10-25 \mathrm{~cm}$. The orientation of the dunes roughly orthogonal to the prevailing wind direction suggests they are predominantly influenced by wind-driven wave currents, although the wave energy is markedly lower than on the main shoal crest west of Little Ambergris Cay due to the proximity to Big Ambergris Cay. The northernmost edge of this inter-cay shoal is characterized by a steep northdipping foreset with $\sim 30-40 \mathrm{~cm}$ of vertical relief from the adjacent incipient hardground, indicating northern progradation of this part of the inter-cay shoal associated with currents that wrap around the end of the runway and through the channel between Big and Little Ambergris Cays, likely locally influenced by tidal rather than wave-induced currents. Dunes in the inter-cay shoal are superimposed by centimeter-scale wave ripples with $\sim 10 \mathrm{~cm}$ wavelengths. Sediment transport was intermittent and predominantly in the bed-load regime (Supplemental Movie S1), agitated by gentle wave-driven currents during our observation period. Mean water depth is $\sim 1 \mathrm{~m}$ and the inter-cay shoal remains submerged even at low tide.

Ooid sands in foreshore environments define a narrow belt several meters wide along the shore of Little Ambergris Cay. In this setting, ooids occur in centimeter-scale symmetrical wave ripples with $\sim 15 \mathrm{~cm}$ wavelengths. Elongate bars that extend from east to west across tidal channels which feed into the interior lagoon suggest that there is also a component of longshore transport. Comparison of drone imagery of tidal channel bars in between years indicates significant westward bar elongation, closing off several tidal channels (Supplemental Fig. S3) and corresponding to a minimum westward longshore sediment flux $\sim 2 \mathrm{~m}^{3}$ /

TABLE 2.-Dimensions and abundance of mixed-fabric ooids.

\begin{tabular}{|c|c|c|c|c|c|c|c|c|c|c|}
\hline \multirow[b]{2}{*}{ Sample } & \multicolumn{7}{|c|}{ Dimensional Analysis } & \multicolumn{3}{|c|}{ Point-Counting Data } \\
\hline & $\mathbf{n}^{\mathbf{a}}$ & $\begin{array}{c}\text { Distance from } \\
\text { eastern end of Little } \\
\text { Ambergris Cay }(\mathrm{km})\end{array}$ & $\begin{array}{c}\text { Mean micritized } \\
\text { interior } \\
\text { dimension }^{\mathrm{a}}(\mu \mathrm{m})\end{array}$ & $\begin{array}{c}\text { Standard deviation, } \\
\text { micritized }^{\mathrm{a}}(\mu \mathrm{m})\end{array}$ & $\begin{array}{l}\text { Micritized } \\
\text { interior } \\
\text { aspect ratio }^{\mathrm{a}}\end{array}$ & $\begin{array}{c}\text { Mean } \\
\text { volume } \\
\text { ratio }^{b}\end{array}$ & $\begin{array}{c}\text { Standard } \\
\text { deviation, } \\
\text { volume ratio }^{b}\end{array}$ & $\begin{array}{l}\text { Mixed } \\
\text { fabric }^{c}\end{array}$ & $\begin{array}{c}\text { Fully } \\
\text { micritized }^{c}\end{array}$ & $\begin{array}{c}\text { Fully } \\
\text { pristine }^{c}\end{array}$ \\
\hline OT3 & 119 & 24.4 & 298 & 101 & 1.34 & 0.19 & 0.13 & 65.4 & 13.7 & 20.9 \\
\hline OT7 & 74 & 20.7 & 374 & 123 & 1.27 & 0.32 & 0.17 & 54.9 & 24.0 & 21.1 \\
\hline OT10 & 87 & 18.4 & 321 & 97 & 1.37 & 0.28 & 0.16 & 58.3 & 23.1 & 18.6 \\
\hline OT15 & 72 & 12.9 & 316 & 98 & 1.35 & 0.30 & 0.17 & 54.6 & 25.7 & 19.7 \\
\hline
\end{tabular}

${ }^{a}$ Dimensions of micritized interiors of mixed-fabric grains measured from thin sections and corrected by comparing the mean grain dimensions (of grain exteriors) with Camsizer data. The number of grains measured from each sample is given by "n."

${ }^{\mathrm{b}}$ Volume ratio of micritized interior to total grain volume, averaged over all grains measured (given by "n"). Volumes were estimated using major-axis and intermediateaxis dimensions measured from thin sections and assuming an ellipsoidal shape with equal intermediate-axis and minor-axis dimensions.

${ }^{\mathrm{c}}$ Sample compositions determined via point counting thin sections. Total number of points for each sample was 350 . 
day (Supplemental Fig. S4). Sediment transport ranges from near the threshold for motion to bedload. Coarse-sand-size skeletal carbonate fragments occur as lags in the ripple troughs in some areas.

Ooids in the main shoal crest environment occur over an area $>8 \mathrm{~km}^{2}$ that defines the dominant geomorphic feature in the system - a linear shoal extending $\sim 20 \mathrm{~km}$ westward from the end of Little Ambergris Cay (Fig. 2 ). The shoal crest is defined by a chevron pattern of asymmetric subaqueous dunes (also referred to as "sand waves" by previous authors), with mean wavelengths of $28 \mathrm{~m}(\mathrm{n}=196, \sigma=7 \mathrm{~m})$ (Fig. 3C) and amplitudes of $30-50 \mathrm{~cm}$. The mean dip directions of dunes are $329^{\circ}(\mathrm{n}=$ $\left.138, \sigma=9^{\circ}\right)$ on the northern side of the shoal crest and $237^{\circ}(\mathrm{n}=58, \sigma=$ $11^{\circ}$ ) on the southern side of the shoal crest (Fig. 3D). The steeper lee slopes of dunes are noticeably less consolidated than stoss slopes or troughs, consistent with loosely packed sediment deposited by grain avalanches. Oscillation ripples with $\sim 20-30 \mathrm{~cm}$ wavelengths and $\sim 1-3$ $\mathrm{cm}$ amplitudes occur on the stoss slopes of most dunes. These ripples commonly wash out and then reform over short timescales ( $<30$ seconds). Ooids are transported near the threshold of suspension by combined-flow currents, and the upper water column is relatively free of sediment, with little washload material (Supplemental Movie S2). Emergent hardgrounds and hardground intraclasts occur in $\sim 100 \mathrm{~cm}^{2}$ patches in the troughs between dunes, suggesting that the dunes may be migrating over a relatively stable hardground surface. The hardground intraclasts are too large to be transported by typical wave currents; this observation, combined with the asymmetry in distribution of hardground intraclasts between the northern and southern flanks of the shoal crest noted by Rankey et al. (2008), suggest that the transport and re-sedimentation of these intraclasts is associated with storms. Mean water depth over the shoal crest varies systematically from $\sim 0.5$ to $2 \mathrm{~m}$, with the shallowest depths to the east and the deepest regions in the western end of the shoal. At low tide, dune crests are exposed in the shallow eastern part of the shoal crest within $\sim 5 \mathrm{~km}$ of Little Ambergris Cay; the rest of the shoal crest is always submerged. Dunes are less well-defined and emergent hardgrounds are less common in the western end of the shoal crest.

Landsat data were used to calculate an average displacement of dunes along the overall shoal crest strike over one year (2016) of $0.44 \pm 0.18 \mathrm{~m} /$ day (Supplemental Movie S3). Given the $\sim 20 \mathrm{~km}$ length of the shoal crest as a minimum ooid transport path, this dune migration rate implies a timescale on the order of $\sim 125$ years for an individual bedform to traverse the length of the shoal crest under fair-weather conditions. Typical particle hop lengths of $\sim 500 \mu \mathrm{m}$ ooids for observed transport modes (bed load to suspended load) are less than $1 \mathrm{~m}$ (see Supplemental Material), whereas the mean dune wavelength is $28 \mathrm{~m}$, indicating that most ooids do not simply hop between adjacent dunes to escape burial by grain avalanches on the lee slope. The timescale of burial can be estimated by dividing the mean half wavelength of dunes by the migration rate, which yields a burial time of roughly a month. It is therefore reasonable to interpret that, under fair-weather conditions, ooids migrate with the dunes. Ooids also are unlikely to move faster than the dunes during fair-weather conditions because grains commonly stall in the dune lee slope.

Ooid sands in algae-stabilized subtidal environments occur immediately adjacent to higher-energy inter-cay shoal, foreshore, and shoal-crest environments, associated with infrequent sediment transport near the threshold for motion. Sediments there are still predominantly grainy, but mud, which is absent on the shoal crest, is also locally present. Calcifying algae, mainly Halimeda and Penicillus, are abundant and act as baffles for sediment. Incipient hardgrounds are common. Active bed forms, including wave ripples, are typically absent from these environments, although there are some (largely) inactive dunes whose surfaces have been stabilized by calcifying algae. Rankey et al. (2008) examined the flanks of the shoal in detail, documenting similar contrasts in sediment composition and noting asymmetry in the sediment composition between the northern and southern flanks of the shoal.

\section{Data on Ooid Size and Shape}

Ooids from Little Ambergris Cay are medium- to coarse-sand-size with median diameters $\left(D_{50}\right)$ ranging from $271 \mu \mathrm{m}$ in the inter-cay shoal to 606 $\mu \mathrm{m}$ near the western end of the main shoal crest (Fig. 4, Supplemental Table S1). Mean aspect ratios range from 1.15 to 1.31 , mean roundness ranges from 0.88 to 0.92 , and mean sphericity ranges from 0.93 to 0.97 . In general, size and shape data illustrate that Little Ambergris ooids are wellsorted and well-rounded, with high sphericity. Nevertheless, ooids of the four environments differ markedly in terms of $D_{50}$, aspect ratio, roundness, and sphericity (Fig. 4). Ooids from the inter-cay shoal are much finer than other samples, and they exhibit high aspect ratios and low sphericity but higher roundness than ooids from either the foreshore or algae-stabilized subtidal environments. Ooids from the main shoal crest are notable in having the coarsest grain sizes, combined with the lowest aspect ratios and highest roundness and sphericity parameters. Furthermore, shoal-crest samples exhibit a strong covariation between roundness and sphericity that is not observed in other samples (Supplemental Fig. S5).

Shoal-crest ooids also exhibit trends in size and shape, with mean grain size increasing by more than $100 \mu \mathrm{m}$ along the length of the shoal crest in the 2016 sample set, coupled with increases in mean sphericity and roundness and decreases in mean aspect ratio (Fig. 5A-C). The 2017 sample set displays similar trends, although the grain sizes are offset to $\sim 40 \mu \mathrm{m}$ finer than the 2016 sample set. Trends in grain size and shape are smaller in magnitude along the length of the northern foreshore of Little Ambergris Cay, although still displaying the same directionalityincreasing grain size and sphericity and decreasing aspect ratio further west. The grain-size trend along the intertidal-zone transect is not continuous with the trend in the shoal crest - there is a discontinuity in size associated with a sharp $\sim 50 \mu \mathrm{m}$ decrease in $D_{10}, D_{50}$, and $D_{90}$ between the two 2016 sample sets. In contrast, trends in aspect ratio and sphericity appear continuous between foreshore and shoal-crest samples and between 2016 and 2017 samples (Fig. 5A-C). In general, ooid size, sphericity, and roundness increase and aspect ratio decreases westward across all environments.

Rankey et al. (2008) noted decreases in grain size and sorting in transects across the crest of Ambergris shoal. Our samples are consistent with these observations, illustrating a sharp contrast between shoal-crest sands and those in adjacent settings. For example, a sample collected $\sim 10$ $\mathrm{m}$ off the edge of the active shoal (a visually distinct contact) had $D_{50}$ more than $200 \mu \mathrm{m}$ less than a sample collected nearby on the shoal crest (see Supplemental Table S1). There was no significant difference between samples collected on the crest and the leading edge of a single dune, but a sample from the adjacent trough was slightly coarser and less well sorted (see Supplemental Table S1).

\section{Petrography and Electron Microscopy}

Ooids are the dominant grain type (40-94\% of grains; Supplemental Table S2) in sediment samples from all environments. Grapestones were observed in all thin sections and account for $3-52 \%$ of grains. Grapestones were most abundant in algae-stabilized subtidal sediment (52\%) and were modestly more abundant in 2017 shoal-crest samples relative to 2016 samples from the same environment (Supplemental Table S2). Skeletal sand grains and peloids represent $<2 \%$ of grains in shoal-crest sediment but are more abundant in foreshore, inter-cay shoal, and algae-stabilized subtidal sediment $(3-12 \%)$.

With the exception of inter-cay shoal ooids, most Ambergris ooids have well-developed cortices with many laminae (Fig. 6). Ooid nuclei are micritized peloids, skeletal fragments, or, in rare cases, small grapestones. There were no pronounced differences in nucleus composition among samples from different environments. Micritization is pervasive in inter-cay shoal, foreshore, and algae-stabilized subtidal ooids, with varying degrees 


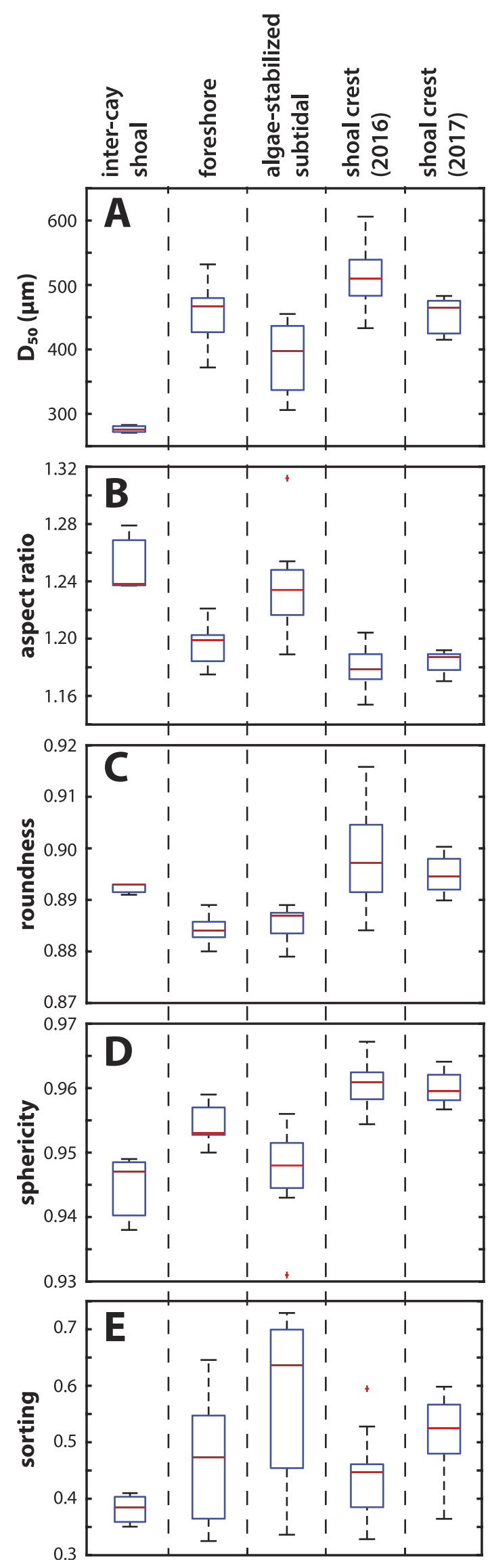

of fabric destruction - primary laminae and nuclei grains remain clearly identifiable in some ooids whereas, at the other extreme, some ooids have no observable primary fabric (Fig. 6). Shoal-crest ooids are distinctly less micritized than inter-cay shoal, foreshore, or algae-stabilized subtidal ooids, with the exception of shoal-crest samples located close to the eastern edge of Little Ambergris Cay. Many shoal-crest ooids show two internal cortical fabrics: a micritized interior cortex and non-micritized texturally pristine exterior cortex (Fig. 6C). The micritized interiors (including nucleus and interior cortex) of these mixed-fabric grains vary in size and shape and are comparable to the micritized inter-cay shoal, foreshore, and algae-stabilized subtidal ooids, with mean sizes range from 298 to $374 \mu \mathrm{m}$ in diameter and mean aspect ratios of 1.27-1.37 (Table 2). Point counting of shoal-crest ooids in thin section reveals that most ooids are dominated compositionally by mixed-fabric grains (55-65\%), with minor populations of fully micritized ooids (14-26\%) and fully pristine (entire cortex is pristine and not micritized) ooids (19-21\%) (Table 2).

Microboring traces and associated organic matter are common on the surfaces and within ooid cortices in ooids from all environments. Some microboring features are closely associated with areas of enhanced micritization (Fig. 6F), although not all micritization appears associated with microboring traces and not all microborings are associated with micritization (Fig. 6E). SEM imaging of ooid surfaces reveals that the "pitting" surface textures observed and characterized via dissecting microscope reflect varying degrees of surface degradation by microboring (Fig. 7A-D), as has been documented in previous studies of ooid surface textures (Harris et al. 1979; Gaffey 1983; Duguid et al. 2010). Polished surfaces are texturally similar to surface polish produced in ooid abrasion experiments (Trower et al. 2017). The proportion of highly polished ooids increases from $3 \%$ to $29 \%$ westward along the length of the shoal crest, whereas the proportion of both moderately and heavily microbored ooids decreases from a combined $62 \%$ to a combined $21 \%$ (Fig. 7E). In general, shoal-crest sediment is characterized by higher proportions of highly polished and slightly microbored grains and lower proportions of moderately and heavily microbored grains than sediments from foreshore, inter-cay shoal, and algae-stabilized subtidal environments (Fig. 7E).

SEM imaging of etched thin sections reveals the morphology of microboring traces in the outer $10-100 \mu \mathrm{m}$ of ooid cortices, preserved as epoxy casts (Fig. 8A, B); similar microboring traces were observed in ooids from all environments. The microborings are similar to morphotypes attributed to the endolithic pseudofilamentous cyanobacterium Hyella, which are common in marine ooids (Al-Thukair and Golubic 1996; Foster et al. 2009; Radtke and Golubic 2011). The orientation, dimensions, and morphologies of microboring traces are most consistent with those described as Hyella tenuior - narrow (2.9-3.8 $\mu \mathrm{m}$ wide), elongate unbranching filaments (Golubic et al. 1975; Radtke and Golubic 2011) - and Hyella caespitosa - clusters of thicker (5.1-8.5 $\mu \mathrm{m}$ wide) branching filaments (Al-Thukair and Golubic 1996; Radtke and Golubic 2011). Diatom frustules belonging to at least two distinct pennate species commonly occur on ooid surfaces (Fig. 8C-E), but are rare within etched thin sections of ooid cortices (Fig. 8F).

FIG. 4.-Box plots of A) median grain size, B) aspect ratio, C) roundness, D) sphericity, and $\mathbf{E}$ ) sorting for all oolitic sediment samples, separated by environment. Each box describes the statistical variation in values of the given parameter $\left(D_{50}\right.$, aspect ratio, roundness, or sphericity) among all samples of a particular environment (inter-cay shoal, foreshore, algae-stabilized subtidal, and shoal crest (2016 and 2017 sample sets): the top and bottom of each box are the 25 th and 75 th percentiles, the red line within the box is the median, and the whiskers show the full range of observations, with outliers marked by a red " + " symbol. 


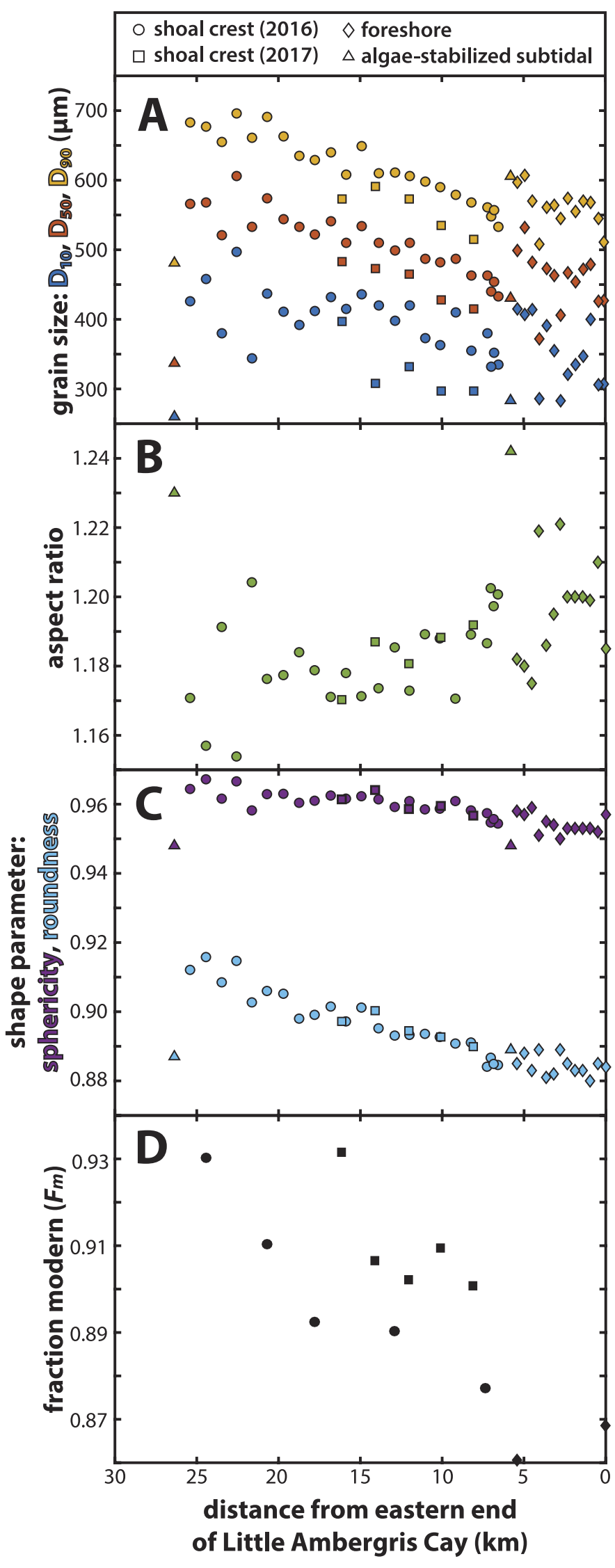

\section{Radiocarbon Data}

Radiocarbon $\left({ }^{14} \mathrm{C}\right)$ is a naturally occurring radioactive isotope of carbon that is incorporated into the carbonate minerals in ooids when they precipitate and subsequently decays as ooids age. The radiocarbon content of a population of ooids, expressed as a fraction of the modern ratio $F_{m}$, is therefore necessarily an average of the individual particles, their nuclei, and cortical layers. Previous authors have developed sequential-dissolution methods to examine trends in $F_{m}$ (and, consequently, age) with depth in ooid cortices and nuclei, although these methods require large sample sizes (35-50 $\mathrm{g}$ of ooids relative to $10-15 \mathrm{mg}$ of ooids used for typical AMS whole-ooid measurements reported here) in order to achieve this resolution due to the low abundance of ${ }^{14} \mathrm{C}$ in natural materials (Duguid et al. 2010; Beaupré et al. 2015). In addition, sequential-dissolution techniques may not be ideal for microbored ooids because the networks of microborings promote uneven dissolution (Beaupré et al. 2015). Due to the variable extent of microboring along the length of the shoal crest (Fig. 8E), wholeooid $F_{m}$ was used here as a tracer to pair with grain-size data to discriminate between hydraulic sorting and ooid growth (Fig. 1). For example, $F_{m}$ should increase in actively growing ooids (resulting in younger bulk ages) as new, younger material is incorporated into the cortex and the volume of the cortex increases relative to the nucleus such that it contributes more significantly to the grain average composition (Fig. 1A, Supplemental Fig. S6). The opposite trend should occur if mixing with adjacent sediments is intense such that newly grown ooids with young carbon are rapidly exchanged with older grains (Fig. 1A). Similarly, $F_{m}$ should decrease (resulting in older bulk ages) for ooids that are either not growing (Fig. 1C) or experiencing diminution via abrasion (Fig. 1B) more rapidly in the latter case as abrasion removes the most ${ }^{14} \mathrm{C}$-rich outermost cortical layers and decreases the volume of the cortex relative to the nucleus. Changes in the abundance of ${ }^{14} \mathrm{C}$ or size of an ooid's nucleus can also drive trends in bulk radiocarbon contents; these effects are evaluated below.

The whole-ooid radiocarbon content of shoal-crest ooids collected in 2016 increases from $0.8772 \pm 0.0018(\sigma)$ near the eastern end of the shoal to $0.9303 \pm 0.0018(\sigma)$ near the western end of the shoal (Fig. 5D). $F_{m}$ values of shoal crest ooids collected in 2017 also increase from 0.9008 $\pm 0.0018(\sigma)$ near the eastern end of the shoal to $0.9316 \pm 0.0018(\sigma)$ halfway along the shoal, $\sim 10 \mathrm{~km}$ from Little Ambergris Cay (Fig. 5D). The absolute values differ between the 2016 and 2017 sample sets, but the slopes of $F_{m}$ versus distance are indistinguishable given the analytical

FIG. 5.-Trends in grain size, shape, and radiocarbon content with distance along the transport path. The direction of transport, as shown on the $\mathrm{x}$ axis, is from right to left (east to west), starting with the eastern end of Little Ambergris Cay $(0 \mathrm{~km})$ and extending to the westernmost end of the shoal $(\sim 27 \mathrm{~km})$ (Fig. 1). Shoal-crest ooids are marked with circles (2016 samples) and squares (2017 samples); foreshore ooids are marked with diamonds (2016 samples only); selected algae-stabilized subtidal samples are marked with triangles (2016 samples only). A) Median grain size $\left(D_{50}\right)$, in addition to 10th $\left(D_{10}\right)$ and 90th $\left(D_{90}\right)$ percentile grain sizes, increase significantly with distance along the shoal, whereas the degree of sorting, as illustrated by the difference between $D_{10}$ and $D_{90}$, does not change significantly. Foreshore samples appear to show a similar trend, although it is defined mainly by the outlying samples on either ends of the transect. The algae-stabilized subtidal sample collected at the western end of the shoal is characterized by distinctly finer grain sizes than the adjacent shoal crest sediment. B) Aspect ratio decreases subtly westward; sediment samples from algae-stabilized subtidal environments do not follow the same trend. C) Sphericity and roundness also increase steadily westward along the shoal crest; although sphericity also increases along the foreshore transect, there is no trend in roundness within the same samples. Again, algae-stabilized subtidal samples do not follow the same trend. D) Radiocarbon Fraction Modern $\left(F_{m}\right)$ increases westward along the shoal crest, indicating a decrease in bulk age of ooids with transport. Error bars on $F_{m}$ are smaller than the symbols, but are shown in Table 3 . The same trend is not observed in foreshore samples. 

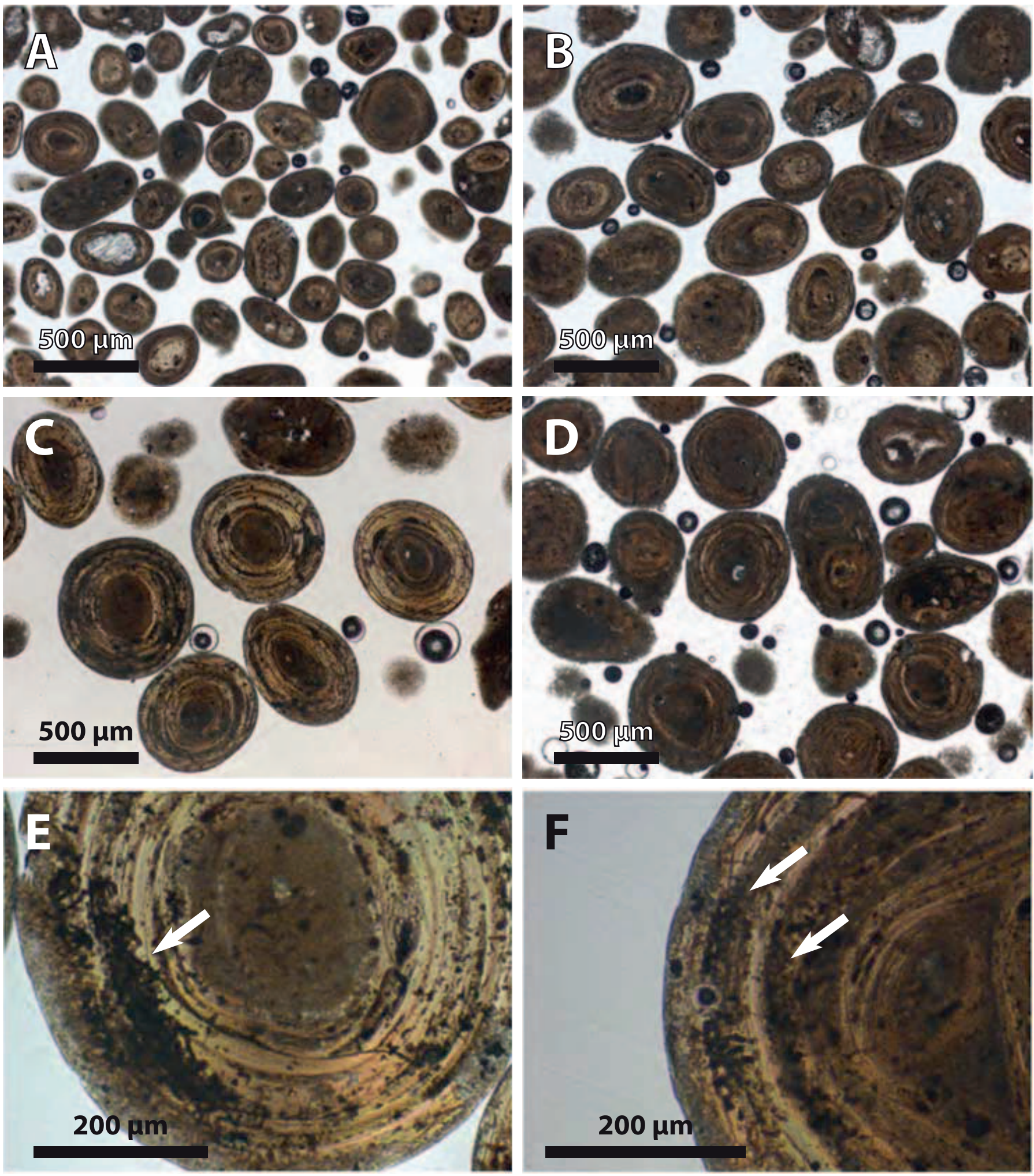

FIG. 6. - Transmitted-light photomicrographs of representative ooids in thin sections from A) inter-cay shoal, B) foreshore, C) shoal crest, and D) algae-stabilized subtidal environments and E, F) examples of microboring traces within ooid cortices. Panels A-D are shown at the same scale, illustrating the notable differences in typical grain size between environments. Ooids from inter-cay shoal, foreshore, and algae-stabilized subtidal environments are pervasively micritized, whereas shoal-crest samples are notably less micritized and typically contain many "mixed fabric" ooids with micritized interiors (including interior cortex and nucleus) and non-micritized exteriors (Table 2). Panels $\mathrm{E}$ and $\mathrm{F}$ illustrate the common occurrence of microboring traces beginning from a particular lamina surface in the ooid cortex and radiating inward. Although microboring traces are commonly associated with local micritization (F, arrows), some microbored zones are not micritized (E, arrow). 

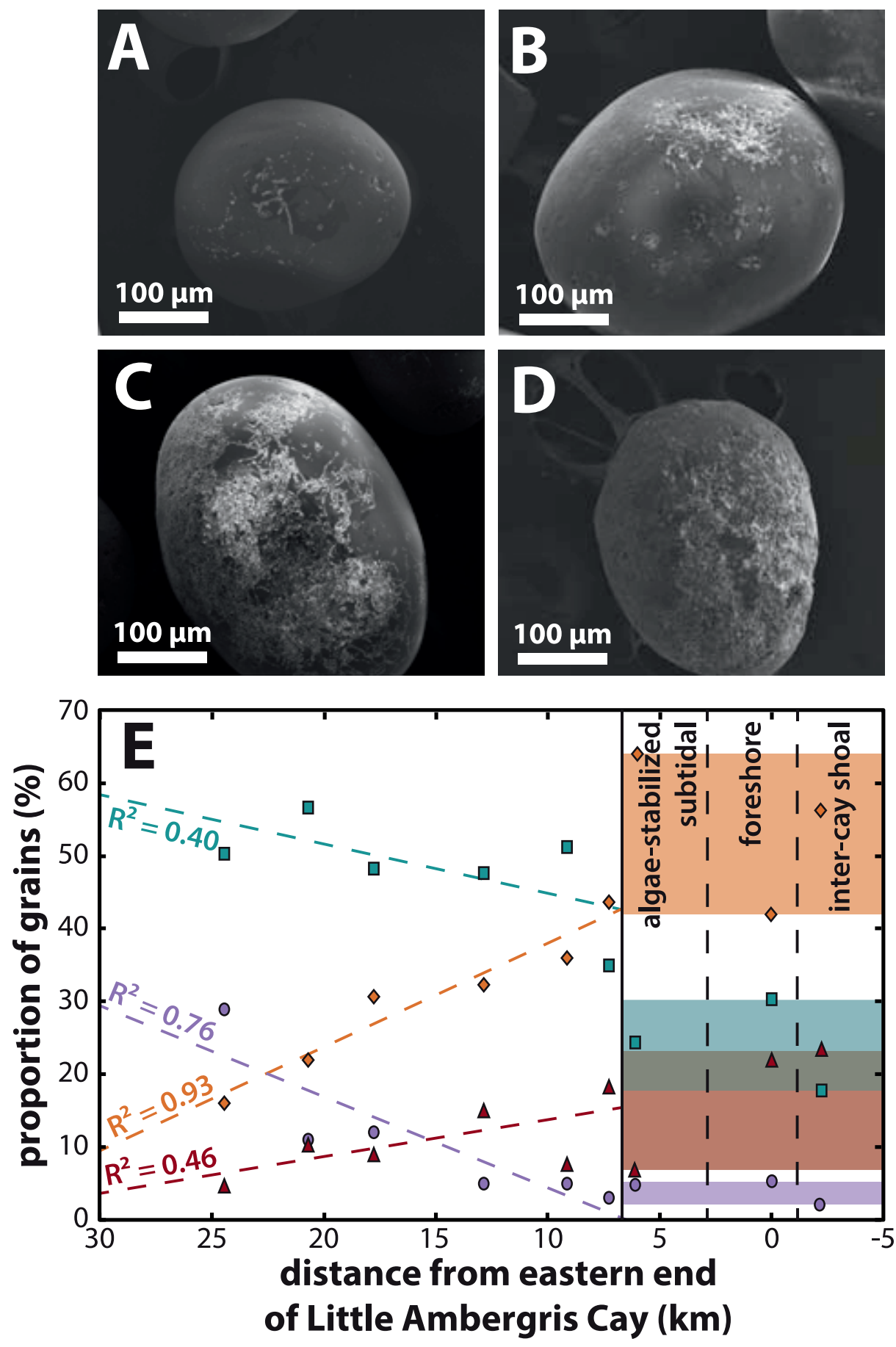

$$
\begin{array}{ll}
\text { O well polished (A) } & \diamond \text { moderate microboring (C) } \\
\square \text { slight microboring (B) } & \Delta \text { heavily microbored (D) }
\end{array}
$$

FIG. 7.- Scanning-electron-microscopy (SEM) images of representative ooid surface textures (AD) and proportions of each surface texture versus distance for select shoal crest samples (E). Ooid surface textures were categorized as A) wellpolished, B) slightly microbored, C) moderately microbored, and D) heavily microbored. E) The proportion of each surface texture in representative sediment samples spanning the length of the shoal crest was determined by point counting 250 grains per sample. The proportions of moderately and heavily microbored ooids decrease farther west along the shoal crest, whereas the proportions of well-polished and slightly microbored ooids increase, likely a result of abrasion during sediment transport. In contrast, representative sediment samples from foreshore, algae-stabilized subtidal, and intra-cay shoal environments have higher proportions of moderately and heavily microbored grains and lower proportions of wellpolished and slightly microbored grains than most shoal-crest samples (colored bars show range of values for these environments). Dashed lines show linear trends fitted to each surface texture type for shoal crest samples. uncertainty (Fig. 5D). Foreshore samples have lower $F_{m}$ than any shoalcrest samples, and the representative sample of ooids from the inter-cay shoal environment has a significantly lower $F_{m}$ than all other samples, $0.7268 \pm 0.0016(\sigma)$, indicating that these ooids are by far the oldest samples analyzed. Given the relatively thin cortices of inter-cay shoal ooids, mass balance suggests that the low bulk $F_{m}$ of these samples may be more reflective of the age of the nuclei rather than age of the cortices for these samples.

Petrographic measurements of the dimensions of the micritized and pristine cortical components of the mixed-fabric ooids from shoal-crest samples were used to test whether trends in radiocarbon content were being driven by cortices, nuclei, or both via a simple mixing model, 

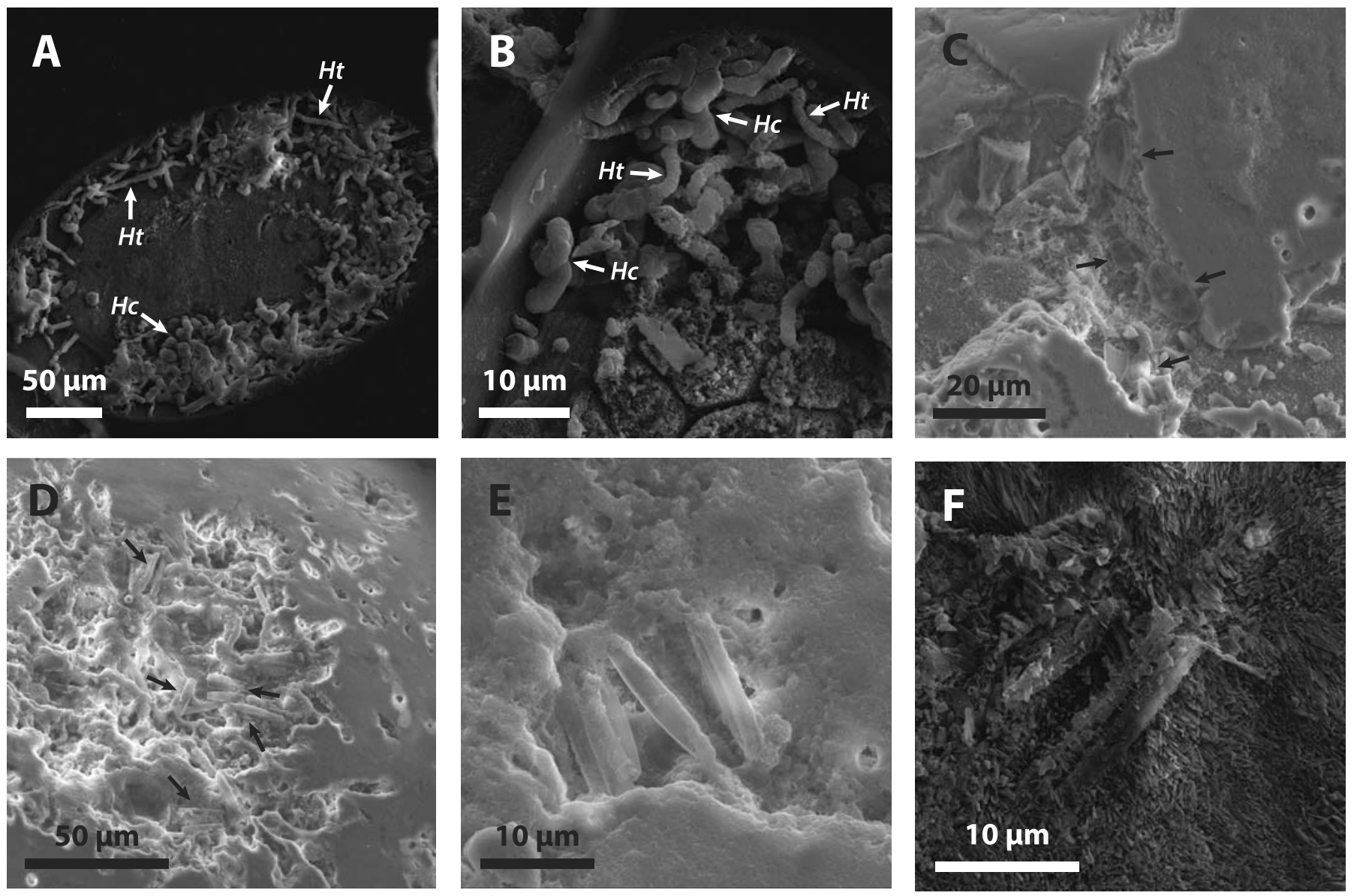

FIG. 8. - SEM images of epoxy-filled microboring traces in acid-etched thin sections (A, B) and diatom frustules on non-etched ooid surfaces (C-E) and within cortices of acid-etched thin sections (F). A, B) Epoxy-filled microboring traces revealed by acid-etching thin sections reveal two distinct morphologies: narrow elongate unbranching traces, which are characteristic of morphotypes attributed to Hyella tenuior (arrows, "Ht"), and clusters of thicker branching filaments, which are characteristic of Hyella caespitosa (arrows, "Hc"). Both traces are commonly co-associated and occur in ooids from all environments examined here. C-E) Diatom frustules from at least two distinct pennate species (arrows) occur in concavities on ooid surfaces. F) Rare diatom frustule preserved in an ooid cortex, as revealed in an acid-etched thin section. The scarcity of frustules in ooid cortices suggests that they are rarely incorporated into the ooid cortex, despite their common occurrence on ooid surfaces.

$$
F_{m, \text { mixture }}=\frac{F_{m, 1} m_{1}+F_{m, 2} m_{2}}{m_{1}+m_{2}}
$$

that relates the radiocarbon content $F_{\text {m,mixture }}$ of a mixture of two components to the radiocarbon contents and masses $m$ of each component (Table 2). In the case of shoal-crest ooids, the two components of the mixing model are the texturally pristine exterior cortex and the micritized interiors, which are themselves older ooids composed of a nucleus and a cortex. The model considers only the average radiocarbon content of this interior, rather than attempting to solve for the radiocarbon content of the nucleus. There are two end-member cases that can be compared with this model: (1) trends in whole-ooid $F_{m}$ are controlled by the composition (i.e., age) of the micritized interior or (2) trends in whole-ooid $F_{m}$ are controlled by the composition of the texturally pristine exterior cortex. Under the first scenario, mass balance requires that the exterior cortices of ooids farther west along the shoal crest have higher $F_{m}$ than those closer to Little Ambergris Cay (Supplemental Fig. S7). Under the second scenario, the model indicates that the interiors (interior cortex and nucleus) of ooids farther west along the shoal crest have higher $F_{m}$ than those closer to Little Ambergris Cay (Supplemental Fig. S7). In either case, the exterior component appears likely to be close to the modern reservoir age $\left(F_{m} \approx\right.$ $0.97)$, suggesting that these outer cortices have accreted quite rapidly; this inference is consistent with observations that the cortices of shoal-crest ooids are commonly pristine with markedly less micritization (Fig. 6) and microboring (Fig. 7D) than ooids from the inter-cay shoal, foreshore, and algae-stabilized subtidal environments.

$$
\delta^{13} C_{\text {carb }}, \delta^{18} O_{\text {carb }} \text {, and } \delta^{34} S_{C A S} \text { Geochemistry }
$$

Carbon-isotope values from the shoal-crest ooids range from 4.69 to $4.78 \%$, and oxygen-isotope values range from -0.27 to $-0.11 \%$ (Table 3 ). There is no trend in $\delta^{13} \mathrm{C}_{\text {carb }}$ or $\delta^{18} \mathrm{O}_{\text {carb }}$ values along the length of the shoal and no correlation between $\delta^{13} \mathrm{C}_{\text {carb }}$ and $\delta^{18} \mathrm{O}_{\text {carb }}$ values; all measurements are within analytical uncertainty of one another. Samples from the inter-cay shoal and algae-stabilized subtidal environments have $\delta^{13} \mathrm{C}_{\text {carb }}$ and $\delta^{18} \mathrm{O}_{\text {carb }}$ values indistinguishable from those of shoal-crest samples. These values fall within the range previously observed in ooids from both Caicos and Bahamian platforms (e.g., Duguid et al. 2010). Carbon-isotope values from seawater DIC range from 0.52 to $1.01 \%$; the average $\delta^{13} \mathrm{C}_{\text {DIC }}$ from shoal-crest seawater samples is $0.85 \%$. CAS sulfurisotope values $\left(\delta^{34} \mathrm{~S}_{\mathrm{CAS}}\right)$ of ooids from inter-cay shoal, shoal-crest, and algae-stabilized subtidal environments range from 22.5 to $22.8 \%$-all samples are isotopically indistinguishable within the limits of uncertainty (Table 3). Seawater sulfate from the shoal crest and the eastern shore of Big Ambergris Cay have identical $\delta^{34} \mathrm{~S}$ values of $21.9 \pm 0.2 \%$. 
TABLE 3.- $\delta^{13} C_{c a r b}, \delta^{18} O_{c a r b}, \delta^{34} S_{C A S}$, and $F_{m}$ results.

\begin{tabular}{|c|c|c|c|c|c|c|c|}
\hline Sample & $\begin{array}{c}\text { Distance from } \\
\text { eastern end of Little } \\
\text { Ambergris Cay }(\mathbf{k m})\end{array}$ & $\begin{array}{c}\delta^{13} \mathrm{C}_{\text {carb,V-PDB }} \\
(\%)^{\mathrm{c}}\end{array}$ & $\begin{array}{c}\delta^{18} \mathrm{O}_{\text {carb,V-PDB }} \\
(\%)^{\mathrm{d}}\end{array}$ & $\begin{array}{c}\delta^{34} \mathrm{~S}_{\mathrm{CAS}, \mathrm{V}-\mathrm{CDT}} \\
\left.(\%)^{\mathrm{e}}\right)^{-}\end{array}$ & $\mathbf{F}_{\mathrm{m}}$ & $\begin{array}{l}\text { Radiocarbon age } \\
\text { (radiocarbon yr) }\end{array}$ & $\begin{array}{c}\text { Corrected } \\
\operatorname{age}^{f}(y r)\end{array}$ \\
\hline OT3 (shoal crest) & 24.4 & 4.78 & -0.11 & 22.77 & $0.9303 \pm 0.0018$ & $580 \pm 15$ & 262 \\
\hline OT7 (shoal crest) & 20.7 & & & & $0.9103 \pm 0.0019$ & $755 \pm 15$ & 435 \\
\hline OT10 (shoal crest) & 17.8 & 4.69 & -0.27 & 22.57 & $0.8924 \pm 0.0024$ & $915 \pm 20$ & 543 \\
\hline OT15 (shoal crest) & 12.9 & & & & $0.8903 \pm 0.0020$ & $935 \pm 20$ & 562 \\
\hline OT25 (inter-cay shoal) & $\mathrm{N} / \mathrm{A}^{\mathrm{b}}$ & 4.66 & -0.18 & 22.60 & $0.7268 \pm 0.0016$ & $2560 \pm 20$ & 2276 \\
\hline OT27 (algae-stabilized subtidal) & $\mathrm{N} / \mathrm{A}^{\mathrm{b}}$ & 4.72 & -0.18 & & & & \\
\hline BT1 (foreshore) & 0 & & & & $0.8685 \pm 0.0019$ & $1130 \pm 15$ & 704 \\
\hline BT13 (foreshore) & 5.4 & & & & $0.8606 \pm 0.0018$ & $1210 \pm 15$ & 783 \\
\hline WMW (seawater) ${ }^{\mathrm{a}}$ & 7.4 & & & 21.9 & & & \\
\hline BASW (seawater) ${ }^{\mathrm{a}}$ & $\mathrm{N} / \mathrm{A}^{\mathrm{b}}$ & & & 21.9 & & & \\
\hline SV5 (shoal crest) & 8.1 & & & & $0.9008 \pm 0.0018$ & $840 \pm 15$ & 494 \\
\hline
\end{tabular}

${ }^{\text {a }}$ Water samples were collected from the shoal crest near the western end of Little Ambergris Cay (WMW) and from the eastern shore of Big Ambergris Cay (BASW).

b These samples do not lie along the beach-shoal transect; location data are available for these samples (see Supplemental Table S1).

${ }^{\mathrm{c}} \delta^{13} \mathrm{C}$ error (based on standard deviation of international standards) is $0.1 \%$.

${ }^{\mathrm{d}} \delta^{18} \mathrm{O}$ error (based on standard deviation of international standards) is $0.3 \%$.

${ }^{\mathrm{e}} \delta^{34} \mathrm{~S}$ error (based on standard deviation of international standards) is $0.2 \%$.

${ }^{\mathrm{f}}$ Ages corrected using CALIB (Stuiver et al. 2017) and assuming a reservoir age of $238 \pm 10 \mathrm{yr}$ (Wagner et al. 2009).

\section{Seawater Carbonate Chemistry}

Seawater geochemical data in Table 4 reveal that seawater salinity ranges from 35 to $37 \%$. Daytime temperatures were 29.4 to $30.1^{\circ} \mathrm{C}$. Field $\mathrm{pH}$ measurements range from 8.13 to 8.20 . Concentrations of dissolved inorganic carbonate (DIC) range from 1.98 to $2.25 \mathrm{mmol} / \mathrm{kg}$, and total alkalinity ranges from 2.30 to $2.53 \mathrm{mmol} / \mathrm{kg}$. Calculated aragonite saturation states in waters around Little Ambergris Cay $\left(\Omega_{\text {aragonite }}\right)$ range from 4.0 to 5.6; shoal-crest seawater samples are modestly more saturated (mean $\Omega_{\text {aragonite }} 5.0$ ) than samples from the inter-cay shoal (mean $\Omega_{\text {aragonite }}$ 4.0) or from the southern shore of Little Ambergris Cay (mean $\Omega_{\text {aragonite }}$ 4.3). The propagation of uncertainty in triplicate DIC analyses results in a precision of $\sim 1$ unit for calculated $\Omega_{\text {aragonite }}$; the saturation states of the seawater samples from the shoal crest are indistinguishable from one another.

\section{$16 S$ rRNA Data}

16S rRNA data illustrate broad similarities in microbial community among ooid samples in different environments, which are all dominated by Proteobacteria, Planctomycetes, Cyanobacteria, Bacteriodetes, and Acidobacteria (Fig. 9). Ooids from the algae-stabilized subtidal environment had more operational taxonomic units OTUs from members of the Deltaproteobacteria and Desulfobacterales - two groups that include

TABLE 4.-Data on seawater carbonate chemistry.

\begin{tabular}{|c|c|c|c|c|c|c|c|c|c|}
\hline Sample ID & Latitude & Longitude & $\mathbf{T}\left({ }^{\circ} \mathbf{C}\right)$ & Salinity $(\% 0)^{\mathbf{a}}$ & $\mathrm{pH}$ & $\mathrm{DIC}^{\mathbf{b}}(\mathbf{m m o l} / \mathbf{k g})$ & $\mathrm{Alk}^{\mathrm{c}}(\mathrm{mmol} / \mathrm{kg})$ & $\delta^{13} C_{\text {DIC }}{ }^{d}(\%)$ & $\boldsymbol{\Omega}_{\text {aragonite }} \mathrm{e}^{\mathrm{e}}$ \\
\hline \multicolumn{10}{|c|}{ Shoal-crest seawater samples } \\
\hline SV1 & 21.30879 & -71.8209 & & 35 & 8.201 & 1.98 & 2.48 & 0.87 & 5.6 \\
\hline SV3 & 21.30298 & -71.7813 & & 37 & 8.159 & 2.10 & 2.53 & 0.89 & 5.2 \\
\hline SV4 & 21.30132 & -71.7624 & & 37 & 8.154 & 2.03 & 2.40 & 0.87 & 4.8 \\
\hline SV5 & 21.29965 & -71.7432 & & 37 & 8.153 & 2.13 & 2.50 & 0.81 & 5.0 \\
\hline WM & 21.29278 & -71.65 & 30.1 & 36 & 8.140 & 2.09 & 2.38 & 0.84 & 4.5 \\
\hline \multicolumn{10}{|c|}{ Inter-cay shoal } \\
\hline AS & 21.29743 & -71.7277 & 29.4 & 36 & 8.146 & 2.25 & 2.44 & 0.64 & 4.0 \\
\hline
\end{tabular}

\footnotetext{
a Precision of salinity measurements is $\sim 1 \%$.

${ }^{\mathrm{b}}$ Precision of DIC measurements ranges from 0.04 to $0.16 \mathrm{mmol} / \mathrm{kg}$ based on triplicate analyses.

${ }^{\mathrm{c}}$ Precision of total alkalinity was $0.018-0.020 \mathrm{mmol} / \mathrm{kg}$.

${ }^{\mathrm{d}}$ Precision of ${ }^{13} \mathrm{C}_{\mathrm{DIC}}$ was $0.05-0.15 \%$ based on triplicate analyses.

e Precision of carbonate saturation state is $\sim 1$ unit based on propagation of uncertainty in DIC data.
} 


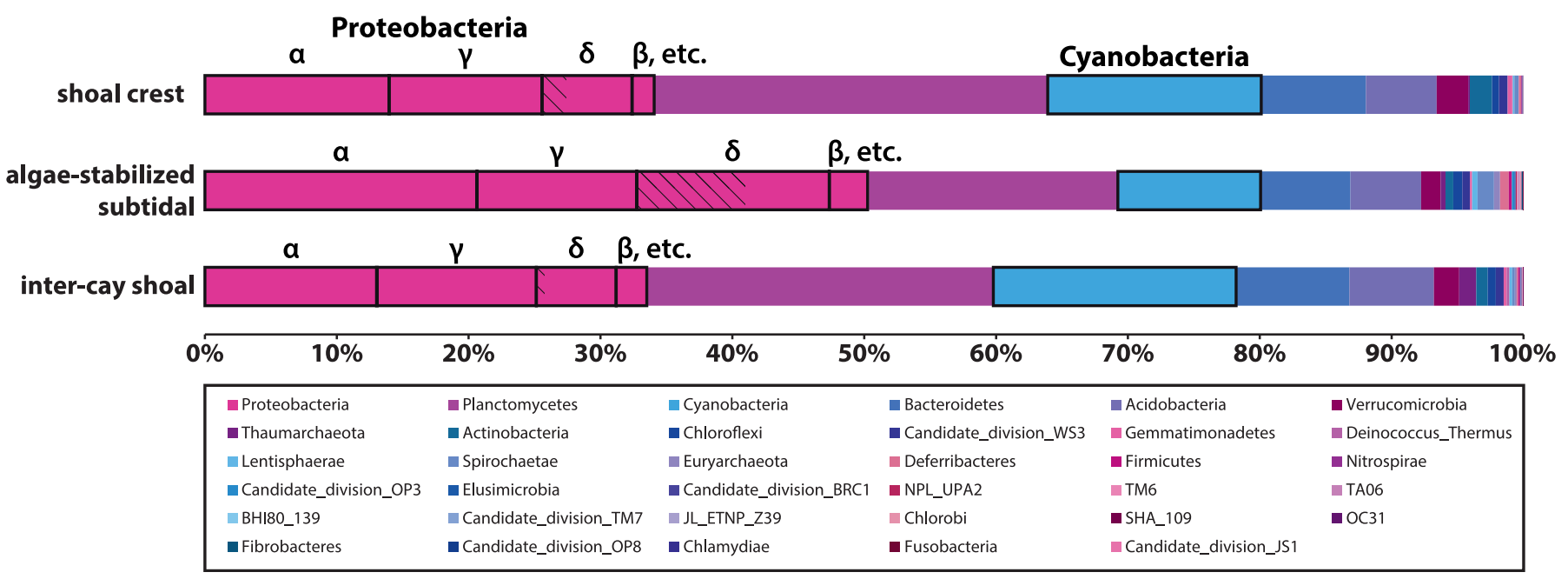

FIG. 9.-Bar charts illustrating microbial community composition at the phylum level in oolitic sediment samples from shoal crest, algae-stabilized subtidal, and inter-cay shoal environments determined via 16S rRNA sequencing. Proteobacteria and Cyanobacteria are highlighted with black lines. Alphaproteobacteria, Gammaproteobacteria, Deltaproteobacteria, and Betaproteobacteria are shown with boxes; within Deltaproteobacteria, Desulfobacterales (the group containing widely distributed sulfate reducers) are shown with diagonal lines. Deltaproteobacteria and, more specifically, Desulfobacterales, are notably more abundant in the algae-stabilized subtidal sample than shoal crest or inter-cay shoal samples.

widely distributed sulfate-reducing bacteria (Kuever 2014); these represent $8 \%$ of bacterial OTUs in this sample, but only $0.6 \%$ in the inter-cay shoal sample and $2 \%$ in the shoal-crest sample. The dominant phyla observed in these samples are comparable to recent observations in Bahamas ooids (Diaz et al. 2013; Edgcomb et al. 2013; O'Reilly et al. 2017).

\section{Lipid Biomarkers}

Algae and Cyanobacteria are the major sources of lipids and biofilm at all sites. This interpretation is based on the dominance of photosynthetic membrane lipids containing long-chain $\left(\mathrm{C}_{20}\right.$ or higher) polyunsaturated fatty acids (algae) or octadecatrienoic acid (Cyanobacteria), the pigments Chlorophyll- $a$, phaeophytin $a, \beta$-carotene and zeaxanthin (algae and Cyanobacteria), and triacylglycerols with long-chain fatty acids (algae). Lipid abundance - a measure of microbial biomass - is over two times higher on the ooids from the algae-stabilized subtidal environments than those from areas of vigorous sediment transport (Supplemental Table S3). The microbial populations in samples from shoal-crest and algae-stabilized subtidal environments are also distinct (Supplemental Figs. S9, S10). In the algae-stabilized subtidal sites most of the increased biomass abundance is associated with algae (triacylglycerols) and bacteria (phosphoglycerolipids and wax esters, Dowhan 1997; Ishige et al. 2003). The shoal-crest ooids are characterized by enhanced abundance of cyanobacterial biomass (photosynthetic membrane lipids containing octadecatrienoic acid) and to a lesser extent other phototrophic bacteria (based on membrane lipids containing $\mathrm{C}_{19}$ fatty acids).

\section{DISCUSSION}

\section{Transport Direction and Timescale}

The Caicos Platform is a wind-dominated carbonate platform with a strong pattern of westward sediment transport (Dravis and Wanless 2008, 2017; Wanless and Dravis 2008). Our field observations support this interpretation of westward sediment transport: the asymmetry of dunes with steeper, less consolidated slopes on the western edges indicates net westward transport. Dune dip directions determined from high-resolution satellite data cluster into two orthogonal sets, the vector sum of which is directed westward (Fig. 3D). The wave refraction pattern and the associated sets of orthogonal dunes appear to be a long-lived characteristic of the Ambergris system based on our field observations and historic observations (Wanless et al. 1989; Dravis and Wanless 2008; Rankey et al. 2008; Bachtel et al. 2011), suggesting that the dunes and their migration are the dominant bedform controlling the rate of fair-weather ooid transport. Westward elongation of tidal-channel mouth bars between 2016 and 2017 also indicates westward longshore transport along Little Ambergris Cay (Supplemental Figs. S3, S4). Accreted Holocene beach ridges on Little Ambergris Cay document this transport mode over thousands of years (Orzechowski et al. 2016). The predominantly unidirectional transport allows analysis of how ooids change as they are transported westward.

Enhanced transport during storms is also likely to affect actual transport timescales, although storm fluxes of ooid sand have yet to be quantitatively constrained. Wanless and Dravis (2008) suggested that storms are responsible for transporting grainy sediment off Caicos Platform, and Bachtel et al. (2011) observed that the amplitudes of dunes on Ambergris shoal were subdued after hurricanes Hannah and Ike in 2008. However, the extent to which these changes reflect redistribution of sediment (i.e., sediment from dune crests infilling troughs), large-scale removal of sediment, or some combination of both is unknown. In the former scenario, storms might have only an incremental effect on long-term ooid transport patterns, while in the latter scenario, storms might be expected to have a significant influence. Caicos Platform was not hit by any major storms in the year between our sampling period, so our data set cannot provide additional insights into storm transport, although it is used below to assess annual-scale variability.

\section{Environments of Ooid Growth}

There are three main hypotheses for where ooid growth occurs. (1) The classic ooid-growth hypothesis predicts that ooid growth should occur in high-energy, current-agitated environments with seawater that is supersaturated with respect to $\mathrm{CaCO}_{3}$ like shoals through either abiotic or microbially mediated mechanisms. In this case, ooids should have higher radiocarbon content and less surface degradation by microboring in these high-energy environments, reflecting in situ growth. (2) In contrast, the hypotheses of quiet-water ooid growth predict that ooid growth should be 


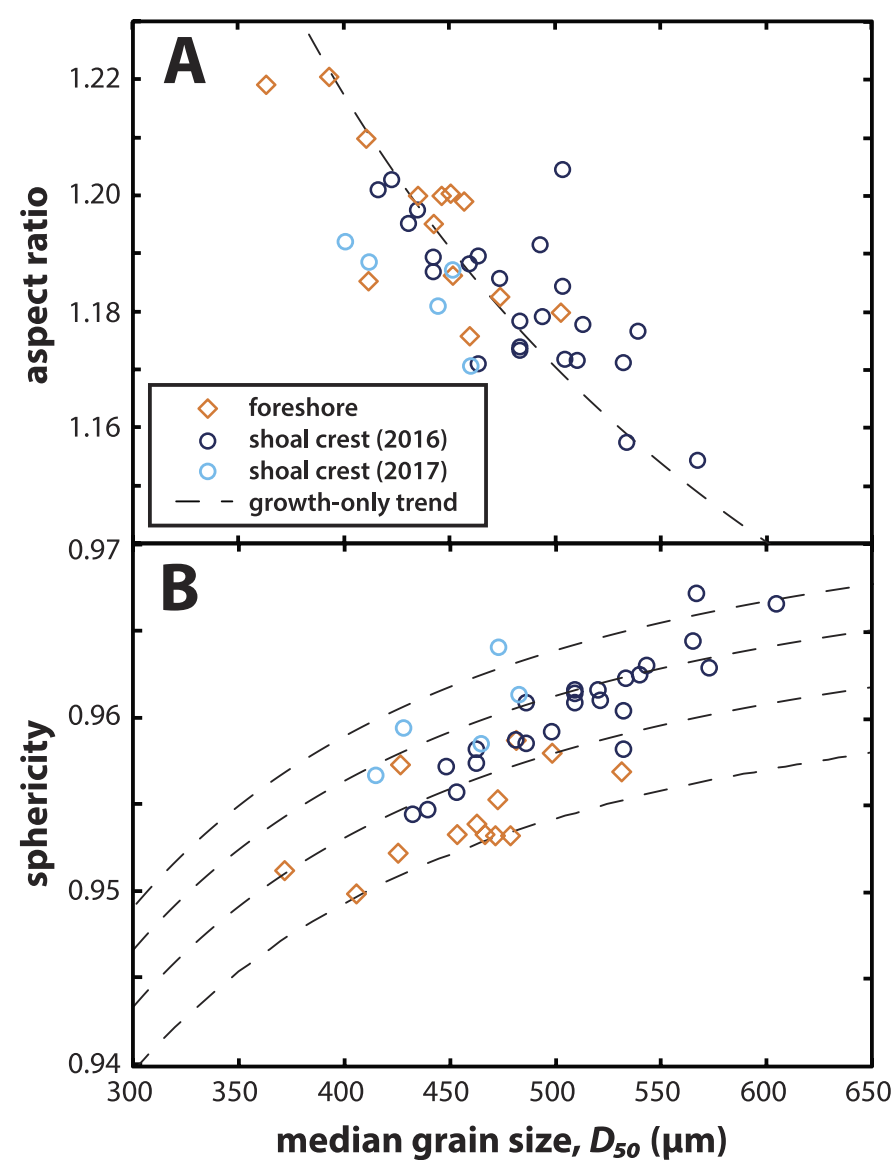

FIG. 10.-A) Mean aspect ratio and B) sphericity versus median grain size $\left(D_{50}\right)$ for foreshore and shoal-crest samples, compared with predicted trends for change in shape as a function of increasing grain size for surface-normal growth. Foreshore and shoal-crest data follow similar trends of decreasing aspect ratio and increasing sphericity with increasing grain size. A) Changes in aspect ratio generally follow the trend predicted for surface-normal growth. B) The relationship between sphericity and grain size depends on particle perimeter, which for natural ooids deviates from that of a perfect smooth ellipsoid; we therefore show a family of curves with different deviations (see Supplemental Material). Notably, the relationship that matches the data of smaller, less spherical ooids significantly underpredicts the sphericity of larger ooids and, vice versa, the curve that matches the data of larger, more spherical ooids significantly overpredicts the sphericity of smaller ooids. The work of abrasion on ooid shape change can readily explain this disparity by driving an additional increase in sphericity, which, when added to a growth-only trend, could produce a relationship with a steeper curve that better matches the data. Therefore, the observed increase in sphericity marks the effect of abrasion, even during net ooid growth.

occurring in deeper environments with less frequent and less energetic sediment transport, like the algae-stabilized subtidal or inter-cay shoal environments. In this case, ooids should have higher radiocarbon content in these environments, whereas ooids in higher-energy, current-agitated settings - such as the main shoal crest - should decrease in both size and radiocarbon content with transport distance due to the combined effects of abrasion and hydraulic sorting. (3) Under the dynamic-equilibrium hypothesis, growth is predicted to result from a combination of carbonate supersaturation and sediment transport mode that favors net precipitation over net abrasion. The environments of growth under this hypothesis could overlap with either of the previous hypotheses; however, the mechanisms driving growth are distinct between the three hypotheses.

Ooid size, shape, petrographic fabric, surface texture, and geochemistry indicate active ooid growth in the main shoal crest, but not in other areas of the Little Ambergris system. Ooid size increases significantly westward along the shoal crest (Fig. 5), whereas inter-cay shoal ooids have by far the smallest grain sizes (Fig. 4). Ooids from the algae-stabilized subtidal environments are also notably smaller than those from foreshore environments or the main shoal crest (Fig. 4). These data are the opposite of the trend predicted by a conceptual model of cumulative abrasion of grains during westward transport (Fig. 1B). Instead, these data suggest that ooids are actively growing as they are transported along the shoal crest. This interpretation is supported further by radiocarbon data $-F_{m}$ increases westward along the shoal crest, indicating that the larger ooids that have been transported farther along the shoal crest have also incorporated more young carbon, whereas foreshore samples have lower $F_{m}$ than any shoal crest samples and inter-cay shoal ooids have even lower $F_{m}$, indicating they are statistically significantly older $(\geq 93.2 \%$ confidence for foreshore, $99.7 \%$ confidence for inter-cay shoal). While we cannot rule out variation of nuclei $F_{m}$ contributing to the radiocarbon trend, the data are consistent with exterior cortex $F_{m}$ close to the modern reservoir age, indicative of recent precipitation, regardless of whether nucleus age is constant or variable (Supplemental Fig. S7).

The new material indicated by shoal-crest $F_{m}$ data is interpreted to reflect additions readily identifiable petrographically as the texturally pristine, non-micritized outer cortices found in shoal-crest ooids but not in other environments. Both the trend in shoal-crest $F_{m}$ data and petrographic observations (Table 2, Fig. 6) are inconsistent with substantial lateral mixing of older ooids into the shoal-crest sediment, which would tend to drive older radiocarbon ages and higher proportions of fully micritized ooids (Supplemental Fig. S8). Notably, the main shoal crest is characterized by more energetic wave-driven currents and larger bedforms than other areas of the Little Ambergris system and is the only area where sediment transport near the threshold of suspension is common during typical fair-weather conditions. Evidence of ooid growth is therefore clearly linked with the most energetic part of the system, which runs counter to predictions of hypotheses of quiet water ooid formation.

Increases in the proportion of highly polished ooids westward along the shoal crest (Fig. 8) suggest that ooids are being abraded as they are transported. Similarly, decreases in the proportions of moderately and heavily microbored ooids westward along the shoal crest (Fig. 8) could result from active ooid growth (new precipitation covering the microbored surface) or abrasion (removal of the microbored surface). However, abrasion reduces grain size in addition to polishing a grain's surface; the westward increase in ooid size combined with the observed increase in polished grains and decrease in microbored grains therefore indicates that ooids are experiencing net growth along with abrasion. Ooid shape data can provide further insights into growth and abrasion because surfacenormal growth and abrasion incrementally affect ooid shape in distinct ways (Sipos et al. 2018). Broadly, aspect ratios decrease and sphericity and roundness increase westward (Fig. 5). To differentiate between shape changes associated with growth and abrasion, the predicted change in ooid shape due to surface-normal growth as a function of increasing grain size can be compared with observed shape changes (Fig. 10, see Supplemental Material). The observed sphericity data diverge from predicted trends for surface-normal growth (Fig. 10B), indicating that grain shapes have been altered by abrasion in addition to surface-normal growth. Thus data on both surface texture and ooid shape illustrate that abrasion plays a role as ooids transit shoal environments - despite overall net growth of the grains.

\section{Mechanisms of Ooid Growth}

In terms of growth mechanisms, the main hypotheses are abiotic precipitation driven by carbonate supersaturation (Bathurst 1975; Swett and Knoll 1989; Sumner and Grotzinger 1993; Duguid et al. 2010) and the mediation or promotion of carbonate precipitation by microbial biofilms (Sumner and Grotzinger 1993; Diaz et al. 2015; Diaz et al. 2017; O'Reilly et al. 2017). Lipid biomarker and 16S rRNA analyses provide information 
on the abundance and community composition of microorganisms present on ooid surfaces, allowing evaluation of whether the organisms present could be responsible for ooid growth. For ooids, both Cyanobacteria and sulfate-reducing microbes have been hypothesized to promote ooid growth because their metabolisms can locally increase carbonate saturation state (Baumgartner et al. 2006; Plée et al. 2008; Diaz et al. 2013; Summons et al. 2013). Both of these microbial mechanisms should also impart an isotopic signature to the precipitated carbonate. Stable-isotope ratios of carbon $\left(\delta^{13} \mathrm{C}_{\text {carb }}\right)$ in carbonate that are lower or higher than the value predicted for abiotic aragonite precipitation from seawater are indicative of microbially mediated carbonate precipitation driven by heterotrophs (e.g., sulfate reducers) or autotrophs (i.e., Cyanobacteria), respectively (Andres et al. 2006). Stable-isotope ratios of sulfur $\left(\delta^{34} S\right)$ in carbonate-associated sulfate (CAS) of aragonite precipitated abiotically from seawater should be heavier by $\sim 1 \%$ than the $\delta^{34} \mathrm{~S}$ value of associated seawater sulfate (Barkan et al. 2014). However, sulfate-reducing microorganisms fractionate sulfur isotopes by preferentially consuming sulfate with the light isotope, ${ }^{32} \mathrm{~S}$, and thereby increase $\delta^{34} \mathrm{~S}$ values of sulfate in the remaining solution (Canfield 2001). Sulfate reduction on grain surfaces should therefore elevate $\delta^{34} \mathrm{~S}_{\mathrm{CAS}}$ beyond the $\sim 1 \%$ fractionation relative to seawater sulfate expected for abiotic precipitation. Thus, data on both microbial diversity and lipid biomarkers provide insight into the abundance of organisms on the ooid surfaces, whereas the stable-isotope-ratio data indicate whether or not the metabolisms of the organisms present play an active role in promoting ooid growth. The latter is important because microorganisms might simply inhabit ooid surfaces, rather than actively grow them.

16S rRNA analyses identified Cyanobacteria and known sulfatereducing microbes (in particular, Desulfobacterales) in samples from shoal-crest, inter-cay shoal, and algae-stabilized subtidal environments. Lipid biomarkers characteristic of Cyanobacteria were observed in samples from all environments. Both data sets illustrate a clear difference in community composition among environments. Lipid data reflect enhanced biofilm development in algae-stabilized subtidal environments, attributed to algae and heterotrophic bacteria, whereas Cyanobacteria and other phototrophic bacteria were more prominent in shoal-crest samples. $16 \mathrm{~S}$ rRNA data illustrated an increased contribution from sulfate-reducing bacteria in the algae-stabilized subtidal environment sample relative to other environments (Fig. 9), again revealing a spatial disconnect between the environment with the greatest evidence for microbial influenceextensive biofilm colonization and occurrence of sulfate-reducers - and the environment with active ooid growth. These data are consistent with previous findings, based on both genomic and lipid data, of a lower extent of biofilm colonization and lower eukaryote abundance when transitioning from low-energy to high-energy settings in Bahamian ooids (Diaz et al. 2014; O’Reilly et al. 2017).

SEM observations indicated extensive, fabric-destructive colonization by endolithic Cyanobacteria in all environments (Fig. 8A, B); thus these endolithic microborers may be an important source of the observed Cyanobacterial lipids and 16S rRNA. Diatom frustules were observed in ooid surface concavities associated with microboring (Fig. 8C-E), but these were only rarely preserved within ooid cortices (Fig. 8F). The degree of surface degradation by microboring - creating microtopographic niches where diatoms collect - is highest in ooids from algae-stabilized subtidal environments; these environments also contain ooids characterized by increased abundances of lipids associated with diatoms and other algae. Together, these observations suggest that the accumulation of diatoms on more heavily microbored ooid surfaces may represent an important source of the observed algal lipids.

Stable-isotope compositions $\left(\delta^{13} \mathrm{C}_{\text {carb }}, \delta^{18} \mathrm{O}_{\text {carb }}\right.$, and $\left.\delta^{34} \mathrm{~S}_{\mathrm{CAS}}\right)$ of ooid samples from shoal-crest, inter-cay shoal, and algae-stabilized subtidal environments are indistinguishable from one another, and are consistent with expectations for abiotic carbonate precipitation. Bulk carbon-isotope compositions are statistically indistinguishable between environments (the mean $\delta^{13} \mathrm{C}_{\text {carb }}$ value is $4.7 \%$, standard deviation $0.1 \%$ ). The mean seawater $\delta^{13} \mathrm{C}_{\mathrm{DIC}}$ value along the shoal crest is $0.88 \%$ (standard deviation $0.13 \%$ ), and the equilibrium fractionation factor between aragonite and DIC is $+2.7 \%$ o $0.6 \%$ at $10-40^{\circ} \mathrm{C}$ (Romanek et al. 1992). The ooid carbon-isotope compositions are within $2 \sigma$ of the expected $\delta^{13} \mathrm{C}_{\text {carb }}$ in equilibrium with Ambergris seawater $\delta^{13} \mathrm{C}_{\mathrm{DIC}}$, so there is no statistical evidence of a microbial influence on ooid $\delta^{13} \mathrm{C}_{\text {carb }}$ (95\% certainty). The absence of a trend in $\delta^{13} \mathrm{C}_{\text {carb }}$ values along the shoal crest, along with the relatively high $\delta^{13} \mathrm{C}$ values, indicates that the observed pattern of increasingly young radiocarbon ages is not driven by differential incorporation of DIC sourced from remineralization of old organic carbon: if samples with older radiocarbon ages (lower $F_{m}$ ) had incorporated more carbonate originating as respired old organic carbon, those samples should have lower $\delta^{13} \mathrm{C}_{\text {carb }}$ values than younger samples-i.e., $\delta^{13} \mathrm{C}_{\text {carb }}$ should covary with $F_{m}$. Bulk oxygen-isotope compositions are also invariant between environments (the mean $\delta^{18} \mathrm{O}_{\text {carb }}$ value is $-0.2 \%$ ), again consistent with aragonite precipitation at or near equilibrium with seawater (Epstein et al. 1953; Swart et al. 2009). CAS sulfur-isotope compositions $\left(\delta^{34} \mathrm{~S}_{\mathrm{CAS}}\right)$ are also statistically indistinguishable among environments (the mean $\delta^{34} \mathrm{~S}_{\mathrm{CAS}}$ value is $22.6 \%, \sigma=0.1, n=5$ ), but on average are about $0.7 \%$ heavier than ambient seawater sulfate $\delta^{34} \mathrm{~S}$ values $(21.9 \pm 0.2 \%)$. This fractionation is consistent with experimental observations of the sulfur-isotope fractionation between abiotically precipitated aragonite and its parent solution (Barkan et al. 2014). Overall, these data suggest that, in the Ambergris system, ooid stable-isotope $\left(\delta^{13} \mathrm{C}_{\text {carb }}, \delta^{18} \mathrm{O}_{\text {carb }}\right.$, and $\delta^{34} \mathrm{~S}_{\text {CAS }}$ ) values are consistent with abiotic ooid carbonate precipitation and the role of microbes may be limited to colonizing and degrading surfaces during non-growth intervals, particularly when ooids are at rest in algae-stabilized subtidal environments.

\section{What are the Primary Controls on Ooid Growth?}

In the Ambergris complex, we observed that ooid growth occurs in the shoal-crest environment through an abiotic, rather than microbial, mechanism. This section explores the underlying controls on this pattern of ooid growth. The absence of evidence for microbial control on ooid growth suggests that carbonate chemistry, transport mode, or both drive ooid growth on the Ambergris shoal. Carbonate saturation state $\left(\Omega_{\text {aragonite }}\right)$ of seawater is higher along the shoal crest than in inter-cay shoal or algaestabilized subtidal environments (Table 4); a more rapid precipitation rate resulting from higher $\Omega_{\text {aragonite }}$ could plausibly drive ooid growth. Dominant fair-weather sediment transport mode also differs between the shoal crest and other environments: ooids are transported near the threshold of suspension on dune crests along the shoal crest, whereas other environments are characterized dominantly by bedload transport. A decreased abrasion rate resulting from increased suspended-load transport could also plausibly drive an increase in equilibrium ooid size (Trower et al. 2017). Finally, the intermittency of grain movement varies between environments as a function of the dominant bedform in which ooids are temporarily trapped. The dunes in the shoal-crest environment result in longer durations between active movement than ripples (Anderson and Cowan 2017; Trower et al. 2017), so sediment in foreshore and algaestabilized subtidal environments experience less intermittent transport resulting in higher time-averaged abrasion rates. However, the surface textures of sediment from these environments are dominantly moderately microbored (Fig. 7), which is consistent with the more extensive biofilm colonization in these environments observed in lipid data.

Observed conditions can be used to test whether the model of dynamic equilibrium ooid size predicts the correct grain size (Trower et al. 2017). Using inputs of $\Omega_{\text {aragonite }}=5$ (shoal-crest average), bed shear velocity $u *=$ $0.03-0.06 \mathrm{~m} / \mathrm{s}$ (this range of values describes threshold of suspension transport for the grain sizes observed on the shoal crest), and intermittency 
factor $f=0.1-0.25$ (equivalent to ooids spending several days in motion for each month buried in a dune), the model predicts equilibrium ooid sizes $\left(D_{e q}\right)$ ranging from 472 to $641 \mu \mathrm{m}$, consistent with the observed range of grain sizes (Supplemental Fig. S11). Changing any of the conditions-for example, decreasing $\Omega_{\text {aragonite }}$ to 4 or decreasing bed shear velocity $<0.03$ $\mathrm{m} / \mathrm{s}$ and increasing intermittency factor (i.e., to describe the intermittency associated with ripples rather than dunes) - causes the model to predict finer grain sizes, consistent with observations of ooid sizes in foreshore, inter-cay shoal, and algae-stabilized subtidal environments (Supplemental Fig. S11). On the Ambergris shoal, therefore, the model of dynamic equilibrium ooid size suggests that carbonate chemistry and transport mode and frequency are driving net ooid growth together. Furthermore, our data suggest that carbonate saturation state and transport mode may be related: $\Omega_{\text {aragonite }}$ is highest along the shoal crest, consistent with enhanced $\mathrm{CO}_{2}$ degassing driven by increased wave agitation. The shoal-crest average $\Omega_{\text {aragonite }}$ is $\sim 0.85$ higher than average $\Omega_{\text {aragonite }}$ in seawater samples from inter-cay shoal and algae-stabilized subtidal environments; even a large temperature gradient of $10^{\circ} \mathrm{C}$ between these environments would explain only a $\sim 0.3$ increase in $\Omega_{\text {aragonite }}$.

There are similar trends in grain size and radiocarbon content between the 2016 and 2017 shoal crest sample sets - both grain size and $F_{m}$ increasing westward - although there is also an offset in the 2017 data to finer grain sizes and higher $F_{m}$ (Fig. 5A, D). The offsets imply that the populations of ooids at any individual location along the shoal crest are dynamic, even over annual timescales. The 2017 and 2016 shoal-crest sample sets also differ subtly in terms of average proportion of grapestones (9.2\% in 2016 samples vs. $13.8 \%$ in 2017 samples; Supplemental Table S2) and sorting (2017 samples are somewhat more poorly sorted than 2016 samples; Fig. 4E). The development of grapestones requires that the grains have remained stationary on or within the bed long enough to be cemented together, which suggests that the recent history of sediment transport mode and frequency may have differed between the 2016 and 2017 shoal-crest sample sets.

On the other hand, the persistence of the trends between years is striking, suggesting that the gradients in ooid size and radiocarbon content may be inherent properties of shoal crest sediment, regardless of the individual histories of grains. In other words, physicochemical characteristics of the shoal-crest environment that remain stable beyond annual timescales might be locally recorded in physical (e.g., grain size) and geochemical (e.g., radiocarbon content) properties of the sediment there. The trend in ooid size (Fig. 5A) can be explained by either a gradient in $\Omega_{\text {aragonite }}$, sediment transport mode, and/or intermittency along the length of the shoal crest drives a gradient in equilibrium ooid size (Supplemental Fig. S12) or a single equilibrium size that ooids approached episodically, with growth hindered by long periods of burial within dunes (Supplemental Fig. S13). Since there is no consistent trend in $\Omega_{\text {aragonite }}$ along the length of the shoal crest (Table 4), a gradient in transport mode and frequency is the most plausible explanation this pattern, which is consistent with our observation that the morphology of shoal-crest dunes varies with distance. The bedform-scale morphology of the shoal was altered by Hurricane Ike in 2008 (Bachtel et al. 2011), but the westward coarsening of ooid size along the shoal crest is the opposite of the trend expected for hydrodynamic sorting, which predicts that sediment becomes finer along its transport path. The trend in grain size must therefore have either persisted from before Hurricane Ike or developed over the $\sim 8$ years between the hurricane and our 2016 sampling. Examining the temporal evolution of sediments on the shoal after the recent Hurricane Irma (September 2017) could prove valuable in determining how the pattern of ooid sizes and radiocarbon ages is affected by major storms. Regardless, this observation of this distinct pattern of grain size less than a decade after a major hurricane disturbance suggests that storms affect the distribution of ooid sizes along the shoal crest only transiently, before the physicochemical environment re-establishes an equilibrium.

Traditionally, conceptual models of ooid growth have focused on a linear series of steps in time: nucleation followed by alternating growth and resting stages. A key implication of these models is that properties like ooid size are considered a function of time, which is problematic because the nuclei compositions, cortical stratigraphic patterns, and geochemistry of ooids provide imperfect records of grain histories. A common assumption, for example is that larger ooids have spent more time in an environment with optimal growth conditions - the "ooid factory" - than smaller ooids. Along the shoal crest in the Ambergris complex, median ooid sizes do increase westward and, given the westward net transport of sediment in this system, those larger grains have spent more time in the shoal-crest environment. However, the data show that grain size drops off abruptly at the western end of the shoal crest (Fig. 5A), indicating that shifts in the physicochemical environment, not simply integrated time in the shoal-crest setting, are the key control on ooid size in the Ambergris system.

The Ambergris complex is a unique system in that the sediment transport patterns permit the deconvolution of time and environment as drivers of changes in ooid properties. Nevertheless, the interpretations here are salient for all oolitic systems including in tidal and lacustrine systems. The well-sorted nature of ooid sands observed in a range of environments is commonly interpreted as a result of hydrodynamic sorting, with the implicit assumption that grains in a population share an evolutionary history of nucleation and growth. Sequential radiocarbon dating techniques hinge on the assumption of a shared history because they require averaging ages over large sediment sample sizes. If grain nucleation ages and growth histories are heterogeneous, the interpretations of their sequential age records become less meaningful. However, the alternative interpretation supported by the data presented here is that ooid populations are well-sorted because the sizes of grains are continually, dynamically adjusting their size to the environment. This hypothesis can be further tested in other systems by comparing sediment characteristics across gradients in carbonate saturation state and sediment transport mode. This revised conceptual framework has value for interpreting the rock record of oolitic sediments because ooid size can be used as a record of the most recent physicochemical conditions that grain experienced before it was buried.

\section{CONCLUSIONS}

The wave-driven westward transport of ooids along Little Ambergris Cay and Ambergris shoal provides a test of hypotheses for the formation of ooids, particularly in identifying the environments and mechanisms associated with ooid growth. Multiple lines of evidence demonstrate that ooids grow during their transport along the shoal crest - a high-energy environment characterized by frequent sediment transport near the threshold of suspension. Although the extent of biofilm colonization and the abundance of sulfate-reducing bacteria is greater in quieter-water environments, similar to observations reported in previous studies, shape, microscopy, and radiocarbon data show that ooids are not actively growing in these lower-energy algae-stabilized subtidal environments. Furthermore, stable-isotope data are most consistent with abiotic precipitation of aragonite at or near equilibrium with seawater, rather than through a microbially mediated mechanism. Data on grain shape and surface texture indicate that abrasion plays an important role in ooid genesis, even in environments where ooids experience net growth. Spatial trends in ooid size and radiocarbon content persist on timescales greater than one year. Both carbonate saturation state and sediment transport mode are key controls on where and why ooids are growing in the Little Ambergris system, whereas microbes appear to play a dominantly fabric-destructive role. 


\section{SUPPLEMENTAL MATERIAL}

Supplemental material is available from JSR's Data Archive: https://www. sepm.org/pages.aspx?pageid=229.

\section{ACKNOWLEDGMENTS}

We thank Hannah Grotzinger, Kyle Metcalfe, Emily Orzechowski, Daven Quinn, Leigh Anne Riedman, Sophia Roosth, Elizabeth Sibert, and Max Tarika for their assistance in the field. We thank Stephanie Moore (Washington University in St. Louis), Xiaolei Liu (Massachusetts Institute of Technology), Kat Dawson (Rutgers University), Fenfang Wu (California Institute of Technology, and John Naviaux (California Institute of Technology) for technical support and David Fike (Washington University in St. Louis) and Roger Summons (Massachusetts Institute of Technology) for access to facilities. We thank Bevo and Roger Tarika, Paul Mahoney, and James Seymour for logistical support on Big Ambergris Cay. We thank Frank Corsetti, Noah Planavsky, and one anonymous reviewer for their constructive comments. We thank the Department of Environment and Coastal Resources (DECR), Ministry of Tourism, Environment, Heritage and Culture (MTEHC) of the Turks and Caicos Islands Government for granting us access to do research on Little Ambergris Cay. NOSAMS is supported by the National Science Foundation (NSF) Cooperative Agreement OCE-1239667. EJT acknowledges support from an Agouron Geobiology Postdoctoral Fellowship. SOR acknowledges support from the Marie Skłodowska-Curie Actions Programme and the Irish Research Council (ELEVATE Postdoctoral Fellowship ELEVATEPD/2014/47) and from the National Aeronautics and Space Administration (NASA) Astrobiology Institute (NNA13AA90A). This work was supported by the Agouron Institute and an American Chemical Society Petroleum Research Fund Grant \#56757ND8 (to WWF).

\section{REFERENCES}

Al-Thukair, A.A., And Golubic, S., 1996, Characterization of Hyella caespitosa var arbuscula var. nov. (Cyanophyta, Cyanobacteria) from shoaling ooid sand grains, Arabian Gulf: Nova Hedwigia Beiheft, v. 112, p. 83-92.

ANDERSON, N.T., AND CoWAN, C.A., 2017, Implications of the bedform phase diagram for size-dependent changes of ooid cortical fabric [Abstract]: American Geophysical Union Fall Meeting: New Orleans, Louisiana.

Andres, M.S., Sumner, D.Y., Reid, R.P., and Swart, P.K., 2006, Isotopic fingerprints of microbial respiration in aragonite from Bahamian stromatolites: Geology, v. 34, p. 973 976.

Bachtel, S., Kerans, C., and Bachtel, C.I., 2011, The Sedimentary Influences of Hurricanes Hannah and Ike (September 2008) on the Caicos Platform, B.W.I.: Do HighEnergy Storms Impact Sedimentation on Carbonate Platforms? [Abstract]: American Association of Petroleum Geologists, Annual Conference, Houston, Texas, Proceedings.

BALL, M.M., 1967, Carbonate sand bodies of Florida and the Bahamas: Journal of Sedimentary Petrology, v. 37, p. 556-591.

Barkan, Y., Paris, G., Sessions, A.L., Adkins, J.F., And Halevy, I., 2014, Relating the concentration and isotopic composition of carbonate associated sulfate to parent solutions: Mineralogical Magazine, v. 77, p. 124.

Bathurst, R.G.C., 1975, Carbonate Sediments and Their Diagenesis: Amsterdam, Elsevier, Developments in Sedimentology 12, $620 \mathrm{p}$.

Baumgartner, L.K., Reid, R.P., Dupraz, C., Decho, A.W., Buckley, D.H., Spear, J.R., PrZekop, K.M., AND Visscher, P.T., 2006, Sulfate reducing bacteria in microbial mats: changing paradigms, new discoveries: Sedimentary Geology, v. 185, p. 131-145.

Beaupré, S.R., Roberts, M.L., Burton, J.R., and Summons, R.E., 2015, Rapid, highresolution ${ }^{14} \mathrm{C}$ chronology of ooids: Geochimica et Cosmochimica Acta, v. 159, p. 126 138.

Bligh, E.G., AND Dyer, W.J., 1959, A rapid method of total lipid extraction and purification: Canadian Journal of Biochemistry and Physiology, v. 37, p. 911-917.

Burdett, J.W., Arthur, M.A., And Richardson, M., 1989, A Neogene seawater sulfur isotope age curve from calcareous pelagic microfossils: Earth and Planetary Science Letters, v. 94, p. 189-198.

CANFIELD, D.E., 2001, Isotope fractionation by natural populations of sulfate-reducing bacteria: Geochimica et Cosmochimica Acta, v. 65, p. 1117-1124.

Caporaso, J.G., Kuczynski, J., Stombaugh, J., Bittinger, K., Bushman, F.D., Costello, E.K., Fierer, N., Peña, A.G., Goodrich, J.K., And Gordon, J.I., 2010, QIIME allows analysis of high-throughput community sequencing data: Nature Methods, v. 7, p. 335336.

Caporaso, J.G., Lauber, C.L., Walters, W.A., Berg-Lyons, D., Huntley, J., Fierer, N., Owens, S.M., Betley, J., Fraser, L., and Bauer, M., 2012, Ultra-high-throughput microbial community analysis on the Illumina HiSeq and MiSeq platforms: The ISME Journal, v. 6, p. $1621-1624$

Case, D.H., Pasulka, A.L., Marlow, J.J., Grupe, B.M., Levin, L.A., and Orphan, V.J., 2015, Methane seep carbonates host distinct, diverse, and dynamic microbial assemblages: MBio, v. 6, p. e01348-01315.

Davies, P.J., Bubela, B., and Ferguson, J., 1978, Formation of ooids: Sedimentology, v. 25 , p. $703-730$.

Degnan, P.H., and Ochman, H., 2012, Illumina-based analysis of microbial community diversity: The ISME Journal, v. 6, p. 183-194

Diaz, M.R., Piggot, A.M., Eberli, G.P., And Klaus, J.S., 2013, Bacterial community of oolitic carbonate sediments of the Bahamas Archipelago: Marine Ecology Progress Series, v. 485 , p. $9-24$.

Diaz, M., Van Norstrand, J., Eberli, G.P., Piggot, A., Zhou, J., and Klaus, J., 2014, Functional gene diversity of oolitic sands from Great Bahama Bank: Geobiology, v. 12, p. 231-249.

Diaz, M.R., Swart, P.K., Eberli, G.P., Oehlert, A.M., Devlin, Q., Saeid, A., and Altabet, M.A., 2015, Geochemical evidence of microbial activity within ooids: Sedimentology, v. 62, p. $2090-2112$

Diaz, M.R., Eberli, G.P., Blackwelder, P., Phillips, B., and Swart, P.K., 2017, Microbially mediated organomineralization in the formation of ooids: Geology, v. 45, p. 771-774.

Dowhan, W., 1997, Molecular basis for membrane phospholipid diversity: Why are there so many lipids?: Annual Review of Biochemistry, v. 66, p. 199-232.

DRAVIS, J.J., AND WANLESS, H.R., 2008, Caicos platform models of Quaternary carbonate deposition controlled by stronger easterly Trade Winds-application to petroleum exploration, in Morgan, W.A., and Harris, P.M., eds., Developing Models and Analogs for Isolated Carbonate Platform-Holocene and Pleistocene Carbonates of Caicos Platform, British West Indies: SEPM, Core Workshop Notes, v. 22, p. 21-27.

DRAVIS, J.J., AND WANLESS, H.R., 2017, Impact of strong easterly trade winds on carbonate petroleum exploration: relationships developed from Caicos Platform, southeastern Bahamas: Marine and Petroleum Geology, v. 85, p. 272-300.

Duguid, S.M.A., Kyser, T.K., James, N.P., and Rankey, E.C., 2010, Microbes and ooids: Journal of Sedimentary Research, v. 80, p. 236-251.

Edgcomb, V.P., Bernhard, J.M., Beaudoin, D., Pruss, S.B., Welander, P.V., Schubotz, F., Mehay, S., Gillespie, A.L., And Summons, R.E., 2013, Molecular indicators of microbial diversity in oolitic sands of Highborne Cay, Bahamas: Geobiology, v. 11, p. 234-251.

Epstein, S., Buchsbaum, R., Lowenstam, H.A., and Urey, H.C., 1953, Revised carbonatewater isotopic temperature scale: Geological Society of America, Bulletin, v. 64, p. $1315-1326$.

Fabricius, F.H., 1977, Origin of Marine Ooids and Grapestones, in Fuchtbauer, H., Lisitzyn, A.P., Milliman, J.D., and Seibold, E., eds., Contribution to Sedimentology, 7: Stuttgart, E. Schweizerbart'sche Verlagsbuchhandlung, p. 1-113.

Ferguson, J., Bubela, B., And Davies, P.J., 1978, Synthesis and possible mechanism of formation of radial carbonate ooids: Chemical Geology, v. 22, p. 285-305.

Flügel, E., 2013, Microfacies of Carbonate Rocks: Analysis, Interpretation and Application: Berlin, Springer, $976 \mathrm{p}$.

Foster, J.S., Green, S.J., Ahrendt, S.R., Golubic, S., Reid, R.P., Hetherington, K.L., and Bebout, L., 2009, Molecular and morphological characterization of cyanobacterial diversity in the stromatolites of Highborne Cay, Bahamas: The ISME Journal, v. 3, p. 573-587.

GAFFEY, S.J., 1983, Formation and infilling of pits in marine ooid surfaces: Journal of Sedimentary Petrology, v. 53, p. 193-208.

Golubic, S., Perkins, R.D., and Lukas, K.J., 1975, Boring microorganisms and microborings in carbonate substrates, in Frey, R.W., ed., The Study of Trace Fossils: Berlin, Springer, p. 229-259.

Harris, P.M., AND Ellis, J., 2008, Satellite imagery and visualization of the Caicos platform, in Morgan, W.A., and Harris, P.M., eds., Developing Models and Analogs for Isolated Carbonate Platforms: Holocene and Pleistocene Carbonates of Caicos platform, British West Indies: SEPM, Core Workshop Notes, v. 22, p. 29-46.

Harris, P.M., Halley, R.B., and LuKas, K.J., 1979, Endolith microborings and their preservation in Holocene-Pleistocene (Bahama-Florida) ooids: Geology, v. 7, p. 216220

Heller, P.L., Komar, P.D., and Pevear, D.R., 1980, Transport processes in ooid genesis: Journal of Sedimentary Petrology, v. 50, p. 943-952.

Ishige, T., TANI, A., SAKaI, Y., AND Kato, N., 2003, Wax ester production by bacteria: Current Opinion in Microbiology, v. 6, p. 244-250.

Karlen, I., Olsson, I.U., Kallberg, P., and Kilicci, S., 1965, Absolute determination of the activity of two C-14 dating standards: Arkiv Geofysik, v. 4, p. 465-471.

Kinsman, B., 1965, Wind Waves: Their Generation and Propagation on the Ocean Surface: Englewood Cliffs, New Jersey, Prentice-Hall, 676 p.

Kuever, J., 2014, The family Desulfobacteraceae, in Rosenberg, E., DeLong, E.F., Lory, S., Stackebrandt, E., and Thompson, F., eds., The Prokaryotes: Berlin, Springer, p. 45-73.

Lewis, E., Wallace, D., and Allison, L.J., 1998, Program developed for $\mathrm{CO}_{2}$ system calculations: Carbon Dioxide Information Analysis Center, Lockheed Martin Energy Research Corporation, U.S. Department of Energy, Tennessee.

Mackenzie, F., And Pigott, J., 1981, Tectonic controls of Phanerozoic sedimentary rock cycling: Geological Society of London, Journal, v. 138, p. 183-196.

Mariotti, G., Pruss, S., Summons, R., Newman, S., and Bosak, T., 2014, Where is the ooid factory? [Abstract]: American Geophysical Union, Fall Meeting Abstracts, San Francisco, Proceedings. 
Medwedeff, D.A., And Wilkinson, B.H., 1983, Cortical fabrics in calcite and aragonite ooids, in Peryt, T., eds., Coated Grains: Berlin, Springer, p. 109-115.

Mitterer, R.M., 1972, Biogeochemistry of aragonite mud and oolites: Geochimica et Cosmochimica Acta, v. 36, p. 1407-1422.

Neuman, C.J., Crr, G.W., Caso, E.L., and Jarvinen, B.R., 1978, Tropical cyclones of the north Atlantic Ocean, 1871-1977: Asheville, North Carolina, U.S. Department of Commerce, National Climatic Center, National Oceanic and Atmospheric Administration.

Newell, N.D., Purdy, E.G., And Imbrie, J., 1960, Bahamian Oölitic Sand: The Journal of Geology, v. 68, p. 481-497.

NOAA/NOS/CO-OPS, 2016, Hawks Nest Anchorage, Turks Islands: National Oceanic and Atmospheric Administration, Tide Predictions.

Ondov, B.D., Bergman, N.H., and Phillippy, A.M., 2011, Interactive metagenomic visualization in a Web browser: BMC Bioinformatics, v. 12, p. 385.

O’Reilly, S., Mariotti, G., Winter, A., Newman, S., Matys, E., McDermott, F., Pruss, S. Bosak, T., Summons, R., and Klepac-CeraJ, V., 2017, Molecular biosignatures reveal common benthic microbial sources of organic matter in ooids and grapestones from Pigeon Cay, The Bahamas: Geobiology, v. 15, p. 112-130.

Orzechowski, E., Strauss, J., Knoll, A., Fischer, W., Cantine, M., Metcalfe, K., Quinn, D., Stein, N., Gomes, M., And Grotzinger, H., 2016, Age and construction of Little Ambergris Cay bedrock rim, southeastern Caicos Platform, British West Indies [Abstract]: American Geophysical Union, Fall Meeting, San Francisco, Proceedings.

Parada, A.E., Needham, D.M., And Fuhrman, J.A., 2016, Every base matters: assessing small subunit rRNA primers for marine microbiomes with mock communities, time series and global field samples: Environmental Microbiology, v. 18, p. 1403-1414.

Pearson, A., McNichol, A.P., Schneider, R.J., Von Reden, K.F., and Zheng, Y., 1997 Microscale AMS ${ }^{14} \mathrm{C}$ measurement at NOSAMS: Radiocarbon, v. 40, p. 61-75.

Plée, K., Ariztequi, D., Martini, R., and Davaud, E., 2008, Unravelling the microbial role in ooid formation: results of an in situ experiment in modern freshwater Lake Geneva in Switzerland: Geobiology, v. 6, p. 341-350

Pluskal, T., Castillo, S., Villar-Briones, A., and Orešlč, M., 2010, MZmine 2: modular framework for processing, visualizing, and analyzing mass spectrometry-based molecular profile data: BMC Bioinformatics, v. 11, p. 395.

RadTKE, G., AND Golubic, S., 2011, Microbial euendolithic assemblages and microborings in intertidal and shallow marine habitats: insight in cyanobacterial speciation, in Reitner, N., Queric, V., and Arp, G., eds., Advances in Stromatolite Geobiology: Berlin, Springer, Lecture Notes in Earth Sciences, v. 131, p. 233-263.

RANKEy, E.C., AND ReEDER, S.L., 2011, Holocene oolitic marine sand complexes of the Bahamas: Journal of Sedimentary Research, v. 81, p. 97-117.

Rankey, E.C., Riegl, B., and StefFen, K., 2006, Form, function and feedbacks in a tidally dominated ooid shoal, Bahamas: Sedimentology, v. 53, p. 1191-1210.

Rankey, E., Reeder, S., ANd Correa, T., 2008, Geomorphology and sedimentology of Ambergris ooid shoal, Caicos Platform: developing models and analogs for isolated carbonate platforms, in Proceedings Holocene and Pleistocene Carbonates of Caicos Platform, British West Indies: SEPM, Core Workshop, v. 22, p. 127-132.

REEDER, S.L., AND RANKEY, E.C., 2008, Interactions between tidal flows and ooid shoals, northern Bahamas: Journal of Sedimentary Research, v. 78, p. 175-186.

Roduit, N., 2007, JMicroVision: image analysis toolbox for measuring and quantifying components of high-definition images, version 1.2.7, v. 2016.

RomaneK, C.S., Grossman, E.L., And Morse, J.W., 1992, Carbon isotopic fractionation in synthetic aragonite and calcite: effects of temperature and precipitation rate: Geochimica et Cosmochimica Acta, v. 56, p. 419-430.

SAndBerg, P.A., 1983, An oscillating trend in Phanerozoic non-skeletal carbonate mineralogy: Nature, v. 305, p. 19-22.

Siahi, M., Hofmann, A., Master, S., Mueller, C., and Gerdes, A., 2017, Carbonate ooids of the Mesoarchaean Pongola Supergroup, South Africa: Geobiology, v. 15, p. 750-766

Sipos, A.A., Domokos, G., and Jerolmack, D.J., 2018, Shape evolution of ooids: a geometric model: Scientific Reports, v. 8, p. 1758.

Sparks, A.G., AND RanKey, E.C., 2013, Relations between geomorphic form and sedimentologic-stratigraphic variability: Holocene ooid sand shoal, Lily Bank, Bahamas: American Association of Petroleum Geologists, Bulletin, v. 97, p. 61-85.

Stuiver, M., Reimer, P.J., AND Reimer, R.W., 2017, CALIB 7.1 [WWW program]: http:/ calib.org.
Sturt, H.F., Summons, R.E., Smith, K., Elvert, M., And Hinrichs, K.U., 2004, Intact polar membrane lipids in prokaryotes and sediments deciphered by high-performance liquid chromatography/electrospray ionization multistage mass spectrometry-new biomarkers for biogeochemistry and microbial ecology: Rapid Communications in Mass Spectrometry, v. 18 , p. 617-628.

Subhas, A.V., Rollins, N.E., Berelson, W.M., Dong, S., Erez, J., And Adkins, J.F., 2015, A novel determination of calcite dissolution kinetics in seawater: Geochimica et Cosmochimica Acta, v. 170, p. 51-68.

Suess, E., AND FÜtTerer, D., 1972, Aragonitic ooids: experimental precipitation from seawater in the presence of humic acids: Sedimentology, v. 19, p. 129-139.

Summons, R.E., Bird, L.R., Gillespie, A.L., Pruss, S.B., Roberts, M.T., and Sessions, A.L., 2013, Lipid biomarkers in ooids from different locations and ages: evidence for a common bacterial flora: Geobiology, v. 11, p. 420-436.

Sumner, D.Y., and Grotzinger, J.P., 1993, Numerical modeling of ooid size and the problem of Neoproterozoic giant ooids: Journal of Sedimentary Petrology, v. 63, p. 974 982

Swart, P.K., Reijmer, J., AND Otto, R., 2009, A reevaluation of facies on Great Bahama Bank II: variations in the $\delta^{13} \mathrm{C}, \delta^{18} \mathrm{O}$ and mineralogy of surface sediments, in Swart, P.K., Eberli, G.P., McKenzie, J.A., Jarvis, I., and Stevens, T., eds., Perspectives in Carbonate Geology: A Tribute to the Career of Robert Nathan Ginsburg: International Association of Sedimentologists, Special Publication 41, p. 47-59.

Swett, K., AND KNoll, A.H., 1989, Marine pisolites from Upper Proterozoic carbonates of East Greenland and Spitsbergen: Sedimentology, v. 36, p. 75-93.

Torres, M.E., Mix, A.C., And Rugh, W.D., 2005, Precise $\delta^{13} \mathrm{C}$ analysis of dissolved inorganic carbon in natural waters using automated headspace sampling and continuousflow mass spectrometry: Limnology and Oceanography: Methods, v. 3, p. 349-360.

Trower, E.J., Lamb, M.P., AND Fischer, W.W., 2017, Experimental evidence that ooid size reflects a dynamic equilibrium between rapid precipitation and abrasion rates: Earth and Planetary Science Letters, v. 468, p. 112-118.

VAN Ee, N.J., AND WANLESS, H.R., 2008, Ooids and grapestone: a significant source of mud on Caicos Platform, in Morgan, W.A., and Harris, P.M., eds., Developing Models and Analogs for Isolated Carbonate Platforms, Holocene and Pleistocene Carbonates of Caicos Platform, British West Indies: SEPM, Core Workshop Notes, v. 22, p. 121-125. Van Heuven, S., Pierrot, D., Rae, J., Lewis, E., and Wallace, D., 2011, Matlab Program Developed for $\mathrm{CO}_{2}$ System Calculations, ORNL/CDIAC-105b: U.S. Department of Energy, Oak Ridge National Laboratory, Carbon Dioxide Information Analysis Center, gov/ftp/co2sys/CO2SYS calc_MATLAB v1, v. 1, p. 1.

WAdell, H., 1932, Volume, shape, and roundness of rock particles: The Journal of Geology, v. 40, p. 443-451.

Wagner, A.J., Guilderson, T.P., Slowey, N.C., and Cole, J.E., 2009, Pre-bomb surface water radiocarbon of the Gulf of Mexico and Caribbean as recorded in hermatypic corals: Radiocarbon, v. 51, p. 947-954.

Wanless, H., and Dravis, J., 1989, Carbonate environments and sequences of Caicos platform: Field Trip Guidebook, v. 374, p. 75.

WANLESS, H.R., AND Dravis, J., 2008, Role of storms and prevailing energy in defining sediment body geometry, composition, and texture on Caicos Platform: developing models and analogs for isolated carbonate platforms: Holocene and Pleistocene carbonates of Caicos Platform, British West Indies: SEPM, Core Workshop Notes, v. 22 , p. $13-20$.

Wanless, H.R., Dravis, J.J., Tedesco, L.P., and Rossinsky, V., 1989, Carbonate Environments and Sequences of Caicos Platform, with an Introductory Evaluation of South Florida: International Geological Congress, Field Trip T374.

Wilkinson, B.H., Buczynski, C., AND Owen, R.M., 1984, Chemical control of carbonate phases: implications from Upper Pennsylvanian calcite-aragonite ooids of southeastern Kansas: Journal of Sedimentary Petrology, v. 54, p. 932-947.

Wilkinson, B.H., Owen, R.M., and Carroll, A.R., 1985, Submarine hydrothermal weathering, global eustasy, and carbonate polymorphism in Phanerozoic marine oolites: Journal of Sedimentary Petrology, v. 55, p. 171-183.

Wotte, T., Shields-Zhou, G.A., and Strauss, H., 2012, Carbonate-associated sulfate: experimental comparisons of common extraction methods and recommendations toward a standard analytical protocol: Chemical Geology, v. 326, p. 132-144.

Received 27 June 2017; accepted 14 July 2018. 